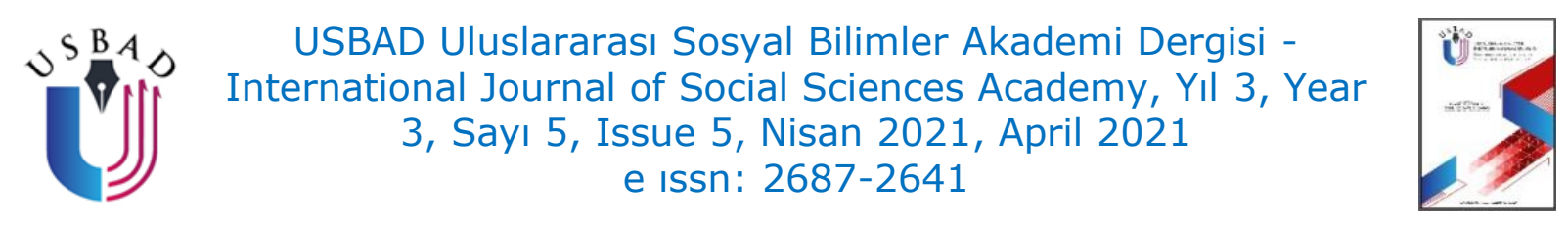

\title{
DUYUSAL PAZARLAMA PERSPEKTİFINDEN KONAKLAMA İŞLETMELERİNDE UYGULANAN DUYUSAL PAZARLAMA UYGULAMALARININ MÜŞTERİ SADAKATİ ÜZERİNDEKİ ETKİSİ
}

\author{
THE EFFECT OF SENSORY MARKETING APPLICATIONS IN \\ ACCOMMODATION ENTERPRISES ON CUSTOMER LOYALTY FROM THE \\ PERSPECTIVE OF SENSORY MARKETING
}

\section{ALİ ELİBOL}

Öğr. Görevlisi, Burdur Mehmet Akif Ersoy Üniversitesi, Yeşilova İsmail Akın Meslek Yüksekokulu, Seyahat-Turizm ve Eğlence Hizmetleri Bölümü, Burdur/Türkiye.

Lecturer, Burdur Mehmet Akif Ersoy University, Yeşilova İsmail Akın Vocational School, Department of Travel-Tourism and Entertainment Services Division, Burdur/Turkey. aelibol@mehmetakif.edu.tr

ORCID ID: 0000-0002-0414-1009

Makale bilgisi | Article Information DOI: $10.47994 /$ usbad. 867280

Makale Türü / Article Type: Araştırma Makalesi / Research Article

Geliş Tarihi / Date Received: 24.01.2021

Kabul Tarihi / Date Accepted: 11.04.2021

Yayın Tarihi / Date Published: 20.04.2021

Yayın Sezonu / Pub Date Season: Nisan / April

Bu Makaleye Atıf İçin / To Cite This Article: Elibol, A. (2021). Konaklama İşletmelerinde Uygulanan Duyusal Pazarlama Uygulamalarının Müşteri Sadakati Üzerindeki Etkisi. USBAD Uluslararası Sosyal Bilimler Akademi Dergisi 3(5), 408-489.

İntihal: Bu makale intihal.net yazılımınca taranmıştır. İntihal tespit edilmemiştir. Plagiarism: This article has been scanned by intihal.net. No plagiarism detected.

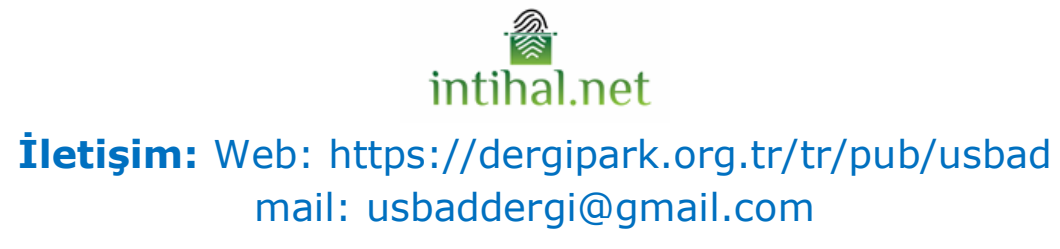


Öz: Günümüzde konaklama işletmeleri hem müşterilerine ulaşabilmek hem de müşterilerinde sadakat duygusunu oluşturabilmek için pazarlama kapsamında çeşitli stratejiler uygulamaktadır. Uyguladıkları bu stratejilerin bir tanesi de duyusal pazarlama stratejisidir. Çünkü bu strateji müşterilerinin akıllarında işletmelerinin canlı kalabilmesini sağlayabilmektedir. Bu kapsam doğrultusunda da günümüz konaklama işletmeleri duyusal pazarlama stratejilerini etkin bir şekilde kullanmaya çalışmaktadırlar. Bu nedenle duyusal pazarlama müşterilerin görme, koklama, duyma, hissetme ve tatma duyu organlarına hitap ederek günümüzde etkili olan pazarlama stratejilerinden biri haline gelmiştir. Konaklama işletmeleri de müşterilerin bu beş duyu organına hitap ederek ve kendilerine özgü yöntemler kullanarak diğer işletmelere karşı hem üstünlük kurmaya hem de diğer işletmelerden farklı olmaya çalışmaktadırlar. Bu araştırmanın temel amacı Burdur ili Yeşilova ilçesinde yer alan Salda Gölü'ne gelen turistler üzerinde duyusal pazarlama uygulamalarının müşteri sadakati üzerindeki etkisini araştırmaktır. Bu kapsam doğrultusunda araştırmanın evrenini Burdur İli ve çevresindeki turizm potansiyel değerleri yüksek olan yerleri ziyarete gelen ziyaretçiler oluşturmaktadır. Fakat günümüzde yaşanan Covid-19 salgını ve kısıtlamalar nedeniyle araştırmaya Salda Gölü'ne gelen 258 yerli turist dâhil edilmiştir. Araştırmada veriler nicel araştırmalarda kullanılan anket tekniğiyle ve kolayda örnekleme yöntemi ile 258 yerli turistle yüz yüze görüşülerek toplanmıştır. Toplanan veriler analiz programına aktarılarak ölçeğin boyutlarını oluşturabilmek için açımlayıcı faktör analizi yapıldıktan sonra korelasyon, basit regresyon, çoklu regresyon, bağımsız örneklem T-testi ve tek yönlü Anova analizleri de yapılmışır. Araştırmada ulaşılan temel sonuç duyusal pazarlama uygulamalarına ilişkin alt boyutlar olan dokunsal, görsel, işitsel, tatsal ve kokusal boyutlar ile müşteri sadakati önermeleri arasında pozitif yönde anlamlı bir ilişki olduğudur. Ayrıca araştırmada müşteri sadakati ile duyusal pazarlama uygulamaları arasında pozitif yönde anlamlı bir ilişki olduğu, dokunsal boyutun kadınlarda erkeklere kıyasla daha önemli olduğu ve evli katılımcıların bekâr katıımcılara göre daha sadık olduğu sonuçlarına da ulaşılmıştır.

Anahtar Kelimeler: Duyu, Duyusal Sistemler, Duyusal Pazarlama, Müşteri Sadakati

Abstract: Currently, accommodation businesses apply various strategies within the scope of marketing in order to both reach their customers and generate a sense of loyalty in their customers. One of these strategies they implement is the sensory marketing strategy. In line with this scope, current accommodation businesses endeavor to use sensory marketing strategies effectively. Therefore, sensory marketing has become one of the effective marketing strategies today by appealing to the sight, smell, hearing, feeling and taste organs of customers. Accommodation businesses also try to be superior to other businesses and differ from other businesses by using their own methods that will appeal to these five senses of customers. The main purpose of this was to investigate the effect of sensory marketing practices on customer loyalty on tourists coming to Salda Lake located in Yeşilova district of Burdur province. In line with this scope, The universe 
of the research consists of visitors who come to visit places with high tourism potential in Burdur Province and its surroundings. However, due to the current Covid-19 epidemic and restrictions, 258 local tourists who came to Lake Salda were included in the study. The collected data were transferred to the analysis program and after the exploratory factor analysis was performed to form the dimensions of the scale, correlation simple, multiple regression, independent sample T-test and one-way ANOVA analyzes were also carried out. The main result of the study is that there is a positive and significant relationship between the subdimensions of sensory marketing applications, which are the tactile, visual, auditory, gustatory and olfactory dimensions, and customer loyalty suggestions, and between customer loyalty and sensory marketing practices. In addition, in the study, it was found that there is a positive significant relationship between customer loyalty and sensory marketing practices, tactile dimension is more important in women than men and that married participants are more loyal than single participants.

Keywords: Sense, Sensory Systems, Sensory Marketing, Customer Loyalty

\section{GİRİ̧̧}

Pazarlama yaşayan bir canlı olgudur (İslamoğlu, 2010: 7). Çünkü geçmişte insanoğlun intiyaçlarını karşılamak ve gidermek için kendine yeterli geldikleri zamanlarda pazarlama olgusu söz konusu değilken daha sonraki yıllarda insanoğlu bu ihtiyaç ve gereksinimleri karşılamada kendi kendisine yetebildiği ev ekonomisinden çıkıp kendi kendilerine yetemedikleri sosyo-ekonomi düzenine geçmişlerdir (Çağlar ve Kılıç, 2010: 3). Bu geçiş ile pazarlama olgusu ortaya çıkmış ve günümüze kadar da araştırmacılar bu olgu üzerinde çalışmalar yaparak yeni teorilerle pazarlama olgusunun gelişimini devam ettirmişlerdir (Çağlar ve Kılıç, 2010: 3; İslamoğlu, 2010: 7). Bu nedenle pazarlama sadece ürünlerin veya hizmetlerin satılması değil daha geniş bir yelpazeye sahip hem süreçler hem de yaklaşımlar bütünüdür.

$\mathrm{Bu}$ yaklaşımlardan bir tanesi tüketicinin bir ürün veya hizmete karşı ilgili algısını, yargısını, kararını ve davranışlarını etkileyen pazarlama stratejisi (Krishna, 2016: 15) olan duyusal pazarlamadır. Duyusal pazarlamanın temel amacı müşterilerin duygularını harekete geçirmek ve müşteriler tarafından işletmenin sunmuş olduğu mal veya hizmetlerin satın alınmasını sağlayarak hem işletmenin markasının müşterilerin zihninde konumlanmasını hem de müşterinin işletme ile duyusal bir bağ kurmasını sağlamaktır (Kaplan, 2015: 85). Bu nedenle günümüz konaklama işletmeleri müşterilerinin beş duyu organlarına hitap edebilecek ve onlarda farklı duygular oluşturabilecek yeni stratejiler uygulamaktadırlar. Bu uyguladıkları stratejide müşterilerin beş duyusuna hitap eden duyusal 
pazarlama uygulamasıdır. Bu uygulama sayesinde konaklama işletmeleri müşterilerine farklı duygular ve farkı deneyimler yaşatarak müşterileri ile işletmeleri arasında bir bağ oluşturmaktadırlar. Bu sayede de konaklama işletmeleri günümüzdeki yaşanan yoğun rekabet ortamında rakiplerine karşı üstünlük elde etmektedirler.

$\mathrm{Bu}$ araştırmanın temel amacı, Burdur ili Yeşilova ilçesinde yer alan Salda Gölü'ne gelen turistler üzerinde duyusal pazarlama uygulamalarının müşteri sadakati üzerindeki etkisini araştırmaktır.

\section{DUYU VE ALGILAMA}

İnsanoğlu merak etme yapısına sahip olduğu için var olduğu günden itibaren çevresindeki varlıkları araştırma, tanıma ve öğrenme çabası içerisindedir. Bundan dolayı tanıma ve öğrenme eğilimi gösteren insanoğlu çevresindekileri anlayabilmek için duyusal bilgileri iki düzeyde işlemektedir. Bu işlemlerden ilki, beş duyu organlarından herhangi biri ile dışarıdan gelen ses, koku, tat, renk vb. uyarıcıların beş duyu organı aracılığıyla algılanması sonucu duyu organlarının ani tepkiler vermesi (Solomon vd., 2006: 37) olarak ifade edilen duyudur. Diğer işlem ise insanoğlunun çevresindeki uyarıcıları seçmesi, organize etmesi ve yorumlaması süreçlerini kapsayan (Çağlar ve Kılıç, 2005: 80) ve dış dünyayı tanıma ve anlamak (Özer, 2009: 2) olarak ifade edilen algılamadır. Bu iki işlem arasındaki en önemli fark ise duyu organları çevresindeki bilgileri toplama aracı olarak işlev görürken algılama ise daha sonra devreye girerek çevresindekileri tanıma ve anlam kazandırma işlevi görmesidir (Koç, 2008: 71 akt. Kahvecioğlu, 2018: 5). Bu nedenle müşterilerin düşünceleri dış uyarıcılarda gördüğü tasarımlardan, renklerden, hissettiği kokulardan, duyduğu seslerden ve temasta bulunduğu varlıklardan ve almış olduğu lezzetlerden etkilenmektedirler (Peck ve Childers, 2008: 193). Hatta Lindstrom beş duyu sisteminden bahsetmiş ve insanoğlunun düşüncelerini etkileyen ve çevresindekileri bilmesini sağlayan görme duyusunu diğer dört duyu sistemini geride bırakarak en etkili ve en güçlü duyu sistemi olarak ifade etmiştir (Lindstrom, 2007: 31). Bunun nedeni gözümüzden beynimize giden sinir sistemi yollarının kulağımızdan beynimize giden sinir sistemi yollarından 25 kat daha uzun olması ve gözümüzün beyin hücreleri içeren tek duyu organımız olmasıdır (Yeygel, 2010: 53). Bu nedenle günümüzdeki konaklama işletmeleri diğer konaklama işletmelerine hem üstünlük sağlamak hem de müşterilerin dikkatini çekmek ve müşteri sadakatini oluşturmak amacıyla işletmelerini estetik şekilde tasarlayıp dizayn ederek, renklendirerek ve ışıklandırarak görsellik boyutlarını oluşturmaktadırlar. İşitme duyu sistemi dış, orta ve iç kulaktan oluşan kulağımız vasıtası ile dışarıdan gelen ses dalgalarının 


\section{Ali Elibol}

saptanması, ayırt edilmesi ve tanımlanması olarak ifade edilmektedir (Sertel ve Özkul, 2014: 131). Dolayısıyla dışarıdan gelen bir ses bireylerin düşüncelerini ve kararlarını etkileyerek bireyleri harekete geçirebilir. Örneğin arabesk bir müzik bireyde keder ve üzüntü oluştururken, daha canlı ve neşeli olan bir pop müzik ise bireye enerji vermektedir. Bu nedenle de konaklama işletmeleri kendilerine özgü müzik veya sesleri kullanarak müşterilerinin düşünce ve kararlarını etkileyebilir ve hatta daha sonra müşteriler o müzik veya sesleri duyduklarında müşterinin zihninde işletmenin canlanmasını sağlayabilir. Diğer duyu sistemi olan tat alma duyu sistemi, ağzımız vasıtasıyla sıvı veya katıların dilimizin üzerinde bulunan tat alıcı hücrelere temas ederek algılanması olarak ifade edilmektedir (Morgan, 2013: 235). Tatlar bireylerin beyninde bazı temel algılara neden olmaktadır. Bundan dolayı bu algıları konaklama işletmeleri kendine özgü kimliklerini oluştururken kullanmaları günümüzde konaklama işletmelerinin tat duyusu üzerine odaklanarak ayrı bir çaba sarf etmelerini zorunlu hale getirmiştir (Yeygel, 2010: 57). Koku duyusu sistemi ise, burnumuz vasıtası ile nesnelerden yayılan koku zerreciklerinin burun zarı üzerindeki sinirlerde uyardığı his olarak ifade edilmekte ve koku alma duyular içinde en esrarengiz olanıdır (Morgan, 2013: 237). Çünkü koku alma duyusu aralıksız 24 saat boyunca devam eden ve bir ortamın iyi ya da kötü olduğunu hemen değerlendirebilen ilk tanımlayıcı mekanizmadır. Koku duyusu bireylerin günlük duyularının \%75'ini etkilediği için bireyin hafızasında önemli bir rölede sahiptir (Kahvecioğlu, 2018: 16-17). Bu nedenle koku işlevsel bir özelliğe sahip olduğu için konaklama işletmeleri restoranlarında, otel odalarında, koridorlarında ve lobilerinde kendilerine has özel kokular kullanarak müşterilerinin duygularını etkileyebilir, beğenilerini arttırabilir, duygu ve heyecan yaşamalarını sağlayabilirler. Diğer dört duyu sisteminden çok daha farklı bir özelliğe sahip olan dokunma duyu sistemi ise, vücudun en büyük parçası olan derinin üzerindeki duyu parçacıklarının bir nesneye doğrudan temas etmesi sonucu ortaya çıkan his olarak ifade edilmektedir (İslamoğlu ve Altunışık, 2013: 135). Bu nedenle bireylerin bir objeden veya nesneden etkilenebilmesi için dokunma duyusu aracılığıyla o objeye veya nesneye dokunması gerekmektedir. Bu fiziksel temas sonucunda bireyde o obje veya nesneye karşı bir duygusal bağ oluşabilmektedir (Kaplan, 2015: 114). Bundan dolayı konaklama işletmeleri oda, lobi, restoran ve bar gibi bölümlerde kullanacakları nesneleri müşterilerinin fiziksel temas etmesi sonucunda otel ve kullanılan nesne ile bir bağ kurabilecek şekilde dizayn ederlerse müşteri sadakati açısından dokunma duyu sistemi önemli bir role sahip olmuş olacaktır. Özellikle hizmet sektöründe ortamın havası, ISıSI, yatak ve mobilyaların rahatlığı, zemin ve duvarların kaplaması gibi unsurlar 


\section{Ali Elibol}

dokunma duyu sistemine yönelik olduğu için önem arz etmektedir (Yeniçeri, 2010: 169). Örneğin İngiltere'de Asta süpermarket zinciri birçok tuvalet kâğıdı markalarını ambalajlarından çıkararak müşterilerin dokunmasını sağlayıp müşterilere markalar arasında kıyaslama imkânı sunmuştur. Bu sayede firma kendi markalarının satışının artmasını sağlamıştır (Lindstrom, 2007: 311). Ayrıca dokunma duyusu müşterilere işletmenin kimliği, ürünlerin kalitesi, içeriği ve dayanıklılığı hakkında bazı mesajlar vermektedir (Yeygel, 2010: 60).

Bireyler duyum sistemlerinden gelen çıkarımlara dayanarak gerçeği algılama düzeylerine göre karar verip harekete geçmektedirler. Çünkü algılama sürecinin ilk aşaması olan duyum bireyin genel algılama sürecini etkilemektedir. Bu nedenle duyum aşamasında dışarıdan gelen görüntü, ses, tat ve koku gibi herhangi bir uyarıcı veya uyarıcılar duyu organlarına gelerek bireylerin ürün veya hizmet değerlendirmelerini önemli düzeyde etkileyebilmektedir (Shiffman ve Kanuk, 1994: 162). Bu kapsam doğrultusunda duyusal uyarıcılar müşterileri ikna etmede ve müşteri sadakatini kazanabilmede en etkili yollardan biri olması sebebiyle konaklama işletmeleri en doğru ve en etkili olan duyusal uyarıcıları kullandıklarından emin olmaları gerekmektedir.

\section{DUYUSAL PAZARLAMA}

Son yıllarda konaklama işletmeleri müşterilerine geleneksel mal ve hizmetler sunsalar da müşterilerinin duygularını yakalayabilecek, duygularında izlenimler bırakabilecek ve müşterilere unutulmaz deneyimler yaşatabilecek hizmetler sunma arzusundadırlar. Bu arzularından dolayı konaklama işletmeleri duyusal sistemleri yaratıcı, kışkırtıcı ve stratejik bir biçimde kullanmaya başlamaları (Stancioiu vd., 2014: 48) günümüzde duyusal pazarlamayı yeni bir pazarlama anlayışı olarak ortaya çıkarmıştır. Özelliklede Krishna müşterileri ikna edebilme ve müşterilerde sadakat duygusunu oluşturabilme açısından duyuların önemli olduğunu anlatmak, pazarlama alanında duyulara olan farkındalığı arttırmak ve eldeki mevcut bilgileri toplayarak duyusal pazarlamayı, pazarlamanın alt disiplini yapmak arzusu ile 2008 yılında bir konferans düzenlemiştir. Krishna'nın düzenlediği bu konferanstan sonra duyusal pazarlama daha kapsamlı şekilde araştırmacılar tarafından ele alınmaya başlanmıştır (Tomaş ve Barutçu, 2017: 151).

Bireyler çevresindeki nesneleri veya çevresinde gelişen olay veya olguları beş duyu organları ile algıladığı için bireyin çevresindeki sesler, koku veya resimler (görüntüler) bireyleri geçmişe götürebilir (Batı, 2018: 168). 
Ayrıca bu duyumlar bireylerde korku, neşe, keder gibi farklı duygular oluşturarak tüketicinin duygularını etkileyebilir ve onu harekete geçirip onun herhangi bir ürün veya hizmeti satın alma kararında etki yaratabilir (Batı, 2018: 168). Bu nedenle duyusal pazarlamanın temel amacı müşterilerin duygularını harekete geçirerek müşteriler tarafından işletmenin sunmuş olduğu mal veya hizmetlerin satın alınmasını, işletmenin markasının müşterilerin zihninde konumlanmasını ve müşterinin işletme ile duyusal bir bağ kurmasını sağlamaktır (Kaplan, 2015: 85). Ayrıca duyusal pazarlama hizmet sektöründe sunulan hizmetin soyut kavramlarını sıcaklık, tasarım, koku ve ses gibi uyarıcıları kullanarak müşterilerin algılarını etkileyip müşterilerin bilinçaltı tetikleyicilerinin harekete geçmesini sağlamaktadır (Krishna, 2016: 142-147). Bundan dolayı duyusal pazarlama tüketicilerin satın alma eyleminde bulunması anında tüketicinin zihninde ne olup bittiğini, duyusal uyaranlara tüketicilerin zihinlerinin nasıl tepki verdiğini ve bunun sonucunda tüketicinin beyinde oluşan bu tetikleyicilerin tüketicilerin karar alma davranışlarına nasıl etki ettiğini araştırmaktadır (Genco vd., 2013: 8-9). Duyusal pazarlama ile ilgili olarak literatürde yapılmış çeşitli tanımlar bulunmaktadır. Amerikan Pazarlama Derneği duyusal pazarlamayı, duyuların kullanılarak tüketicilerin duygu, düşünce ve davranışlarını etkileyip tüketiciyi tahrik edip baştan çıkaracak bir pazarlama stratejisi (Amerika Pazarlama Birliği, Ama.org) olarak tanımlarken Krishna duyusal pazarlamayı tüketicilerin duyularını hedef alarak bu duyuları birleştirip daha sonra tüketicinin bir ürün veya hizmete karşı ilgili algısını, yargısını, kararını ve davranışlarını etkileyen pazarlama stratejisi olarak ifade etmiştir (Krishna, 2016: 15). Bu iki tanımı ve literatürde yer alan tanımlar incelendiğinde duyusal pazarlamayı, tüketicilerin beş duyu sistemine hitap ederek tüketicilerin davranışlarını olumlu yönde etkileyerek mal ve hizmetlerin hem satın alınması hem de tüketici ile işletme arasında duygusal bir bağ oluşmasını sağlayan pazarlama stratejisi bütünü olarak ifade edilmektedir. Aslında Philip Kotler duyuların önemini daha erken fark ederek bir çalışmasında mağaza atmosferinin tüketicilerin satın ama kararlarına etkisinin büyük olduğunu vurgulamasına rağmen duyusal pazarlama uzun yıllar araştırmacılar tarafından inmal edilmiş ve daha sonra modern pazarlama çağında kendine yer bularak bu dönemde daha çok dikkatleri üzerine çekmiştir (Kotler, 1973: 50; Kalay, 2019: 7).

Günümüzde bir işletme müşterilerinin duyularına hitap etmek ve müşterilerine duygusal deneyimler yaşatmak istiyorsa beş duyuya hitap edecek bir pazarlama stratejisini belirlemelidir. Bu stratejiyi belirlerken stratejilerinde kullanacağı uyarıcıları, kanalları, araçları ve müşterilerinde 


\section{Ali Elibol}

uyarmak istediği duyguları dikkatle seçmelidir. Özellikle işletmeler müşterilerinde sadakat oluşturmak ve bu sadakati gelecekte de sürdürebilmek için bütün duyulara hitap edebilen bir strateji belirlemesi gerekmektedir. Çünkü tüm duyulara hitap edebilen bir uyarıcı, diğer uyarıcılara göre kendisini daha önce duyurma ve algılatma şansına sahiptir. Lindstorm (2007) duyuların önemine Şekil 1'de değinmiş ve bir işletmenin müşterilerinin birden çok duyusuna hitap edebilmesi işletmenin müşteriler üzerindeki cezbedici etkisini arttıracağını ifade etmiştir (Lindstrom, 2007: 81).

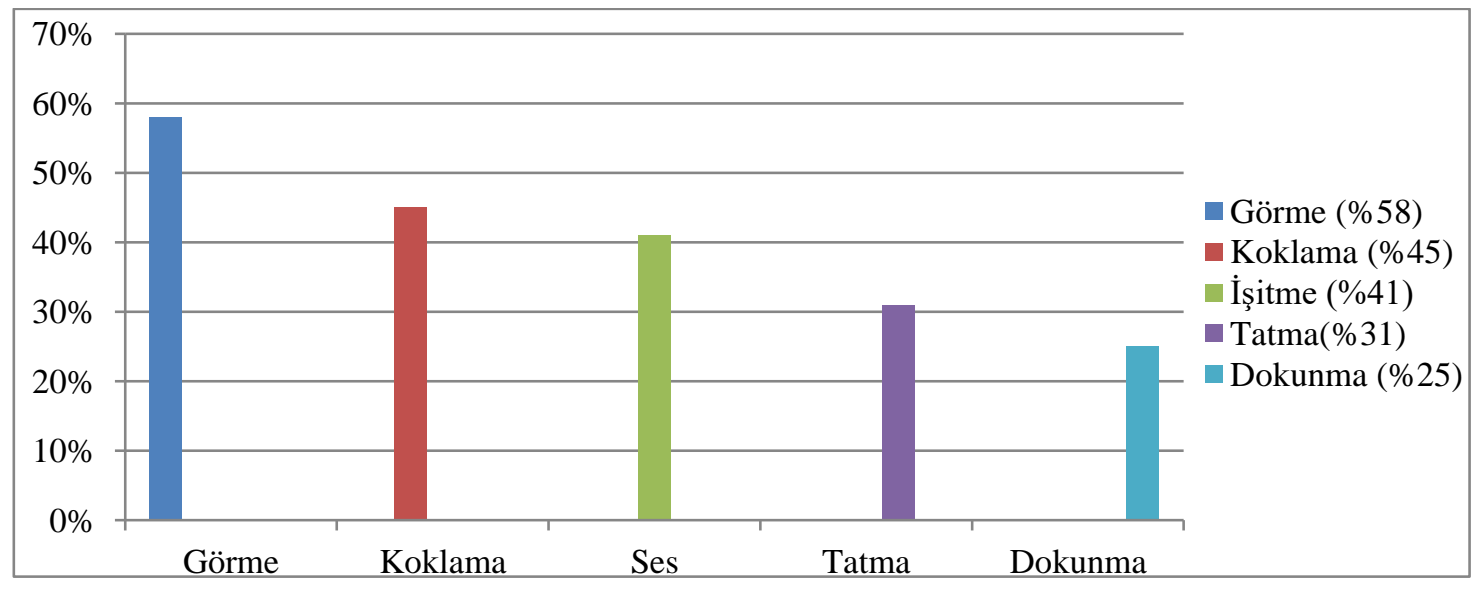

Şekil 1: Beş Duyunun Önemi (Lindstorm, 2007)

Şekil 1'de görüldüğü gibi Lindstorm (2007) duyusal pazarlamada müşterilerin satın alma kararları üzerinde $\% 58$ 'lik bir orana sahip olan görme duyusu, \%25'lik bir orana sahip olan duyu ise dokunmadır. Bu nedenle bir işletme beş duyuya hitap edebilecek bir duyusal pazarlama stratejisi tasarlayabilirse işletmenin lehine olacaktır (Lindstorm, 2007: 81). Günümüzde konaklama işletmeleri artan rekabet ortamında kendilerini rakiplerinden farklı kılabilmek için müşterilerin beş duyusuna yönelik çalışmalar yapmalıdır. Böylece konaklama işletmeleri müşterileri ile arasında duygusal bir bağ kurarak işletmelerini müşterilerin zihninde konumlandırabilecek müşterilerinde sadakat duygusunu oluşturup gelecekte bu sadakatin sürdürülebilmesini sağlayabileceklerdir.

Duyusal pazarlamada pazar yaratma süreçlerine bakıldığında Şekil 1 'deki beş duyunun önemi dikkate alınmakta ve bu temel unsurlar üzerine en etkili olan pazar yaratma stratejisi oluşturulmaya çalışılmaktadır. Bu stratejilerin başında görsellik, pazar yaratma stratejilerinde önemli derecede dikkat çekmektedir. Çünkü görme insan duyumlarının en güçlüsü olduğundan dolayı görsel pazarlamanın temelinde görselleştirme stratejik bir öneme sahiptir. Bu nedenle bir işletme markasının bilinirliğini yaratabilmek, markasının imajını oluşturabilmek, müşterilerinde duyusal 
deneyimlerini belirleyerek duygularına hitap edebilmek için resim, renk, tasarım, stil gibi farklı estetik unsurları diğer rakip firmalardan farklı bir özellik katarak kullanmalıdır (Hulten vd., 2009: 19). Diğer bir pazar yaratma strateji ise bireyin duygularını etkileyen, okşayan ve ruh hallerini ortaya çıkaran ses unsurunun kullanıldığı işitsel pazarlamadır. İşitsel pazarlamanın temelinde işletmeler kendilerine özgü kullandıkları sesler ile müşterilerin işletmeyi diğer rakip işletmelerden ayrıt edilebilirliğini sağlayabilmektedirler. Bu sayede işletmeleri ile müşteriler arasında duygusal bir bağ kurabilmektedirler. Ayrıca Esmailpour ve Zakipour 2016'daki çalışmalarında bir işletmenin markasını oluşturma aşamasında oluşturulan markanın müşteri zihninde daha iyi konumlandırılabilmesi aşamasında görme ve işitme duyusunun bir arada kullanılmasının daha etkili olduğunu vurgulamışlardır (Esmailpour ve Zakipour, 2016: 214). Bir başka pazar yaratma stratejisi, işletmelerin kendilerine özgü kullandıkları ve müşterilerde farklı duyguların ortaya çıkmasını sağlayan kokulardır. Kokusal pazarlamanın temelinde koku duygusunun güçlü etkisi kullanılarak müşterilerde farkındalık yaratmaktır. Özellikle gıda ve kozmetik sektöründe, otel ve konaklama işletmelerinde, avm'lerde, mağazalarda ve restoranlar gibi hizmet sektörlerinde markayı tanımlayıcı bir unsur olarak kendilerine has kokular kullanılmaktadır (Yeygel, 2010: 50). Bireyin tat alma tomurcuklarına hitap eden ve özellikle gıda ve içecek sektörü için önem arz eden diğer bir pazar yaratma stratejisi ise duyusal pazarlamanın tatsal bileşenidir. Çünkü tatsal pazarlamada doğrudan örnekleme yöntemi ile tatlar kullanılarak müşterinin duyguları pozitif yönde etkilenmeye çalışılmaktadır. Örneğin bir mağazada yiyecek veya içeceğin tattırılması markanın müşterilerin akıllarında olumlu yönde algılanmasını sağlamakta ve satışını arttırmaktadır (Esmailpour ve Zakipour, 2016: 215). Çünkü tatlar bireyin duygusal deneyimleri ile bağlantılı olması bireyin ruh halini etkilemekte ve şekillendirmektedir. Bu durum müşterilerin satın alma karar sürecini de etkileyebilmektedir (Matayeva, 2018: 35). Duyusal pazarlamada diğer dört duyu kadar güçlü etkiye sahip olan ve pazarlama alanında önem arz eden son pazar yaratma stratejisi ise duyusal pazarlamanın dokunsal bileşenidir. Çünkü görme sadece göz organı ile, işitme sadece kulak organı ile, tatma sadece ağız organı ile, koklama sadece burun organı ile algılanabilirken dokunma hissi ise vücudun tamamına yayılmıştır (Krishna, 2016: 125). Bu nedenle işletmeler vermek istediği mesajı güçlendirmek ve müşteri deneyimine farklı boyutlar katabilmek için dokunma duyusuna yönelik uyarıcıları kullanmaktadırlar (Yeygel, 2010: 60). Böylece dokunma duygusu hem müşterilerin bilinçaltında yatan merakı karşılamakta hem de 


\section{Ali Elibol}

işletmenin ürününü farklı ve benzersiz kılarak müşterilerde değer yaratmaktadır (Batı, 2012: 213).

Literatür taraması sonucunda ulaşılabilen duyusal pazarlama kapsamında yapılan araştırmalar ve sonuçlar:

Makale Çalışmaları:

Chebat ve Michon'un 2003'te yapmış oldukları araştırmada kullanılan duyusal pazarlama boyutlarının tüketici davranışları üzerindeki etkisini incelemek amaçlanmış ve alışveriş mağazalarında kullanılan kokunun tüketicilerin duygularını etkileyerek tüketicilerin satın alma davranışları ve harcama yapma arzuları üzerinde etkili olduğu sonuçlarına ulaşılmıştır. Lee ve Mahony'in 2005'de yapmış oldukları araştırmada 20 diş macununda kullanılan görsel uyarıcıların tüketici üzerindeki etkisini incelemeyi amaçlanmış ve diş macununda kullanılan açık mavi rengin en ferahlatıcı, kapalı beyaz (off-whites) ve grimsi beyazın (grayish White) en az ferahlatıcı etkiye sahip olduğu sonuçlarına ulaşılmıştır. Raz vd. 2008'de yapmış oldukları araştırmada yenilikçi ürünlerin oluşturulmasına yardımcı olan operasyonel bir protokol oluşturmak için duyusal pazarlama yaklaşımı, yani tüketicileri sürecin farklı aşamalarına dâhil etmek ve göstermek amaçlanmış ve tüketici tercihini yönlendiren ana faktörlerin renk yoğunluğu ile lezzet olduğu ve ürünün ambalaj boyutunun ve etiket türünün tüketici tarafından daha az dikkate alındığı sonuçlarına ulaşılmıştır. Yeygel'in 2010'da yapmış olduğu araştırmada duyuların özellikle kurumsal markalama üzerindeki etkisi incelemek ve markaların örnek uygulamalarını değerlendirmek amaçlanmış ve duyuların kurumsal markalama üzerinde etkili olduğu sonucuna ulaşılmıştır. Krishna'ın 2011'de yapmış olduğu araştırmada duyusal pazarlama perspektifinden duyusal tetikleyicilerin algılama, yargılama ve davranış üzerindeki etkisini incelemek ve duyusal algı ile ilgili araştırmalara genel bir bakış açısı sunmak amaçlanmış ve duyusal pazarlamada incelenmesi gereken çok alanın olduğu ve hala başka duyusal ölçeklerin olmadığı sonuçlarına ulaşılmıştır. Örneğin koku, işitsel ve ihtiyaç ölçekleri gibi. Ayrıca duyusal pazarlama perspektifinde tartışılması gereken birçok kavramında olduğu sonucuna ulaşılmıştır. Örneğin insan yargılarının neye göre şekillendiği veya hangi uyarıcıların bireylerin önyargılarında daha etkili olduğu ve farklı insanlar farklı insanlar tarafından uyandırılabilir mi? Agapito vd. 2012'de yapmış oldukları araştırmada kırsal alanlarda duyusal pazarlama bileşenlerinin turist deneyimleri üzerindeki rolünü incelemek amaçlanmış ve beş duyunun turistlerin deneyim doğasını ve deneyim yoğunluğunu etkilediği sonuçlarına ulaşılmıştır. Wang ve Haizhong'un 2014'de yapmış oldukları araştırmada müşterinin sert dokunuşla 
karşılaştırıldığında yumuşak dokunuşun daha toleranslı tüketici tutumuna yol açtığı ve duyusal pazarlama stratejisinin müşterilerde hizmet memnuniyetini arttırdığı sonucuna ulaşılmıştır. Shabgoush ve Wijayant'nin 2014'te yapmış oldukları araştırmada beş duyuya dikkat çekmek ve bu duyuların tüketici davranışları üzerindeki etkisi incelemek amaçlanmış ve görme, koku alma, duyma, dokunma ve tat duyularının uyarılması tüketici davranışlarını etkilediği ve özellikle beş duyunun aynı anda kullanılması tüketici davranışını daha çok olumlu yönde etkilediği sonuçlarına ulaşılmıştır. Krishna ve Schwarz'nın 2014'te yapmış oldukları araştırmada hangi zihinsel aktivitelerin duyusal deneyime dayandığı, beynin bilgi işleme paradigmasının temel varsayımlarını özetlemek ve tüketicide içeriğe duyarlı algı, imge ve simülasyonun rolünü incelemek amaçlanmıştır. Erenkol ve Ak'ın 2015'te yapmış oldukları araştırmada tüketici algısında duyuların rolünü incelemek amaçlanmış ve duyusal pazarlamada kullanılan ses, tat ve dokunsal duyu bileşenlerinin satın alma kararlarında en etkili duyular olduğu sonucuna ulaşılmıştır. Tosun ve Elmasoğlu'nun 2015'te yapmış oldukları araştırmada duyusal markalamanın sadakat üzerindeki etkisini incelemek amaçlanmış ve duyusal markalamayı en başarılı yapan Coca Coca, Nutella ve Nescafe markalar olduğu ve marka sadakati üzerinde duyusal markalamanın pozitif yönde bir etkiye sahip olduğu sonuçlarına ulaşımıştır. Güzel'in 2015'te yapmış olduğu çalışmada duyusal faktörlerin hislerle ilişkilendirilerek tatil deneyimi üzerindeki etkisini ölçülmek ve bütünsel tatil deneyiminin satın alma sonrası müşteri eğilimlerine yönelik etkilerini incelemek amaçlanmış ve duyusal faktörlerin müşterilerin duygu ve hislerini etkilediği ve pozitif yüklü duygular/hisler ile gelecek müşteri eğilimleri arasında da anlamlı bir ilişki olduğu sonuçlarına ulaşılmıştır. Krishna vd. 2016'da yapmış oldukları araştırmada reklamlarda kullanılan görsellerinin tüketici davranışları üzerindeki rolünü değerlendirmek amaçlanmış ve işitsel duyunun yani reklamlarda kullanılan müziğin tüketicilerin hafızasında etkili olduğu belirtilerek gelecekteki araştırmalar için duyusal pazarlama alanında araştırmalar için uygulama yöntemleri verilmiştir. Randhir'ın 2016'da yapmış olduğu araştırmada duyusal pazarlamanın tüketiciler üzerindeki etkisini analiz etmek amaçlanmış ve duyusal pazarlama bileşenlerinin özellikle KFC tüketicileri için tüketici satın alma davranışı üzerinde pozitif bir etkiye sahip olduğu, müzik gibi duyuları rahatlatıcı ve koklama gibi duyuları ise uyarıcı olarak gördükleri sonuçlarına ulaşılmıştır. Gülmez'in 2017'de yapmış olduğu araştırmada Kahve Dünyası ve Starbucks markalarının beş duyuya nasıl hitap ettikleri ve tüketicilerin marka tercihi üzerindeki etkisini incelemek amaçlanmış ve katılımcılar Kahve Dünyası'nı tat ve dokunma duyuları açısından daha fazla önemserken; Starbucks'ı ise görme, koku ve 


\section{Ali Elibol}

ses duyuları açısından daha fazla önemsedikleri, kadınlarda tat, koku ve ses duyuları Starbucks'ta öne çıkarken, dokunma ve görme duyuları Kahve Dünyası'nda ön plana çıktığı ve erkeklerde ise tat ve dokunma duyuları Kahve Dünyası'nda daha baskın iken, görme ve ses duyuları Starbucks'ta daha baskın olduğu sonuçlarına ulaşılmıştır. Ayrıca araştırmada tüketicilerin markaya ait mağazalara gitme düzeyleri arttıkça, marka tercihlerinde duyuların etkisinin arttığı sonucu saptanmıştır. Bozpolat'ın 2017'de yapmış olduğu araştırmada beş duyu organı dikkate alınarak duyusal faktörlerin tüketici tercihleri üzerindeki etkisini incelemek amaçlanmış ve işletme sahipleri hem satışlarını artırmak hem de müşteri sadakati yaratmak için mağazalarında görsel, işitsel, koku, dokunma ve hissetme ile ilgili atmosferik unsurlara yer vermeleri gerektiği sonucuna ulaşılmıştır. Metin vd. 2017'de yapmış oldukları araştırmada duyusal deneyimlerin etkinlik tatmini üzerindeki etkisini incelemek amaçlanmış ve stadyumun görsel, işitsel ve tatsal deneyimlerin etkinlik tatmini üzerinde anlamlı bir etkiye sahip olduğu ortaya çıkarken kokusal ve dokunsal deneyimlerin etkinlik tatmini üzerinde herhangi bir etkiye sahip olmadığı sonucuna ulaşılmıştır. Ayrıca araştırmada etkinlik tatminin spor tüketim davranışları üzerinde pozitif yönde güçlü bir etkiye sahip olduğu saptanmıştır. Erenkol'un 2017'de yapmış olduğu araştırmada işletmelerin uyguladıkları duyusal markalama stratejilerini ve uyguladıkları stratejilerin marka farkındalığı üzerindeki etkisini incelemek amaçlanmış ve marka farkındalığı ile duyusal markalama arasında pozitif ve anlamlı bir ilişkinin olduğu sonucuna ulaşılmıştır. Ayrıca demografik özellikler arasında gelir ve cinsiyet değişkenlerinin duyusal markalama ile marka farkındalığı arasındaki ilişkiyi farklılaştırıcı bir etkiye sahip olmadıkları sonucu saptanmıştır. Aslan vd. 2017'de yapmış oldukları araştırmada yiyecek ve içecek işletmelerinin duyusal pazarlama farkındalıklarını belirlemek ve işletmelerin kullandıkları duyusal pazarlama uygulamalarını incelemek amaçlanmış ve işletme sahibi ve yöneticilerin duyusal pazarlama ve stratejileri hakkında bir bilgiye sahip olmadıklarına rağmen bu stratejileri uyguladıkları sonucuna ulaşılmıştır. Ayrıca araştırmada yiyecek ve içecek işletmelerinin en çok görsel ve dokunsal kısmen tatsal ve düşük düzeyde işitsel ve kokusal pazarlama stratejilerini uyguladıkları sonucu saptanmıştır. Tomaş ve Barutçu'nun 2017'de yapmış oldukları araştırmada birden fazla duyuya hitap eden yumuşatıcı ürününde görsel bir uyarıcı olarak kullanılan siyah ambalaj renginin, kokunun yoğunluk beklentisi, kokunun yoğunluk algısı ve çamaşırların yumuşaklık beklentisi etkilerini incelemek amaçlanmış ve yumuşatıcı ürününde kullanılan siyah ambalaj renginin; kokunun yoğunluk beklentisi üzerinde etkisi olduğu ama ambalaj içindeki yumuşatıcının kokusunun yoğunluk algısı 
ve çamaşırların yumuşaklık beklentisi üzerine herhangi bir etkiye sahip olmadığı sonucuna ulaşılmıştır. Fahrur ve Wijayanti'nin 2018'de yapmış oldukları araştırmada duyusal pazarlamada kullanılan beş duyu uyarımın müşteri sadakati üzerindeki etkisini ve marka deneyiminin buna nasıl aracılık ettiğini incelemek amaçlanmış ve deneyimsel pazarlama, müşteri sadakati ve müşteri deneyiminin birbiri ile ilişkili bir üçgen oluşturduğu ve duyusal pazarlama bileşenlerinin müşteri sadakatini ve tüketici deneyimini olumlu yönde etkilediği sonuçlarına ulaşılmıştır. Ifeanyichu ve Peter 2018 'de yapmış oldukları araştırmada insan duyularının ve duyusal ipuçlarının sürekli müşteri olma isteği arasındaki ilişkiyi incelemek amaçlanmıştır. Ayrıca araştırmada fast food restoranlarına müşteri sadakatini üzerinde etkili olan duyusal ipuçlarının nasıl uygulayabileceklerini gösterebilmekte a amaçlanmış ve beş duyunun (koku, dokunma, tat, görme ve ses) müşteri üzerinde muazzam ve güçlü bir etkiye sahip olduğu sonucuna ulaşılmıştır. Nadanyiova vd. 2018'de yapmış oldukları araştırmada duyusal pazarlamanın marka değeri üzerindeki etkisini incelemek için çeşitli yabancı ve yerli yazarlardan konuyla ilgili literatür taraması sağlamak amaçlanmış ve yazarlar, müşterilerin sadakatini sağlamak ve yenilerini kazanmak için marka değerini oluştururken duyusal pazarlama stratejilerini kullanmanın faydalı olduğu ve duyusal pazarlamanın marka değeri üzerinde güçlü bir etkiye sahip olduğu sonuçlarına ulaşılmıştır. Ayrıca araştırmada başarılı bir marka oluşturabilmek ve kullanıcılar tarafından marka ile ürünün olumlu algılanması açısından da duyusal pazarlamanın önemli etkisi olduğu sonucuna saptanmıştır. Klaus vd. 2018'de yapmış oldukları araştırmada tüketicilerin duyusal algısını ölçmek için bütünsel bir ölçek geliştirmek amaçlanmıştır. Bu ölçek görsel, akustik, dokunsal, koku alma ve tat algısı olarak beş boyut olarak duyusal algı ürün seti (SPI) olarak tasarlanmış ve pazarlama yöneticilerine tüketiciyi anlamak, ürün tasarımı ve marka iletişimi için önemli bilgiler verilmiştir. Kara ve Temiz'in 2018'de yapmış oldukları araştırmada beş yıldızlı bir termal otelin duyusal markalama bağlamında değerlendirilmesi amaçlanmış ve bağlıık etki puanı değerlerine göre araştırmaya katılan katılımcıların tesisin en fazla görme duyusuna hitap ettiğini ifade etmişler ve bunu sırayla dokunma, ses, tat ve koku duyuları takip etmiştir. Ayrıca araştırmada bağııık etki puanı değerleri de katılımcıların tesiste kalış süreleri, daha önce tesiste konaklama yapma sayıları ve konaklama sektörünü kullanma sıklıklarına göre her bir duyu için artış veya azalış gösterdiği sonucuna saptanmıştır. Güven'nin 2018'de yapmış olduğu araştırmada süpermarket ve hipermarketlerde kullanılan duyusal pazarlama öğelerini (görme, işitme, koku alma, dokunma ve tatma) incelemek amaçlanmış ve süper-hipermarketlerin görsel unsurlarla daha 
çok ilişkilendirildiği, katılımcılar süper-hipermarketin kokusundan etkilendiklerini ve araştırmayla çalınan müziğin koku kadar etkili olmadığı sonuçlarına ulaşılmıştır. Ayrıca araştırmada katılımcıların ürünlere dokunmak istedikleri ve bunun nedenini de ürünlerin kalitelerini değerlendirmek amacıyla yaptıkları sonuçları saptanmıştır. Son olarak araştırmada katılımcıların mağazadan ayrılmalarına en çok neden olan faktörün kalabalık ve koku olduğu sonucu da saptanmıştır. Kalay ve Sümer'in 2019'da yapmış oldukları araştırmada beş duyunun tüketici tercihleri ve demografik değiş̧kenler ile ilişkisini incelemek amaçlanmış ve duyusal pazarlama ile tüketici tercihleri arasında ilişki olduğu ve tüketicilerin çeşitli demografik değişkenlere bağlı olarak duyusal pazarlama faaliyetlerinden farklı düzeylerde etkilendikleri sonuçlarına ulaşılıışır. Akıllıbaş'ın 2019'da yapmış olduğu araştırmada duyusal uyarıcıların tüketici davranışları algısı üzerindeki etkisi incelemek ve duyusal pazarlamanın önemini açıklamak amaçlanmış ve beş duyunun (ses, koku, tat, dokunsal ve görsel) pazarlama stratejilerinde önemli olduğu ve tüketici davranışları algısı üzerinde de önemli bir etkiye sahip olduğu sonuçlarına ulaşılmıştır. Olivia vd. 2019'da yapmış oldukları araştırmada çevrimiçi ortamın duyu organlarını nasıl etkilediğini ve duyusal pazarlama teorilerinin çevrimiçi ortamda tüketici davranışlarını nasıl etkilediğini göstermek amaçlanmıştır. Araştırmanın temel amacı ise duyusal pazarlamayı tanıtmak ve çevrim içi bağlamlarda duyusal pazarlamanın rolü ile ilgili gelecekteki araştırmalara yardımcı olmaktır. Araştırmada sonuç olarak duyusal seçicilerin dijital ortamlar için bir liste sunulmuş ve pazarlamacıların çevrimiçi ortamlarda tüketicilerin duyusal yönlerini etkileyecek yönleri ve yenilikleri vurgulamıştır. Helmefalk 2019'da yapmış olduğu araştırmada mağazalarda uygulanan duyusal pazarlama uygulamalarının tüketicinin satın alma davranışları üzerinde nasıl bir etkiye sahip olduğunu incelemek amaçlanmış ve perakende atmosferindeki çoklu duyusal ipuçlarının, bir arabulucu olarak tüketicinin satın alma davranışını açıkça etkilediği sonucuna ulaşılmışır. Ayrıca duyusal pazarlamada kullanılan çoklu sinyallerin (işitsel, dokunsal, kokusal, görsel) tüketicinin satın alma davranışlarını pozitif yönde etkilediği sonucuna saptanmıştır. Bıswas vd. 2019'da yapmış oldukları araştırmada denge, duruş ve hareket duyusunu oluşturan vestibüler sistemi altıncı duyu olarak adlandırarak duyusal pazarlamanın sınırlarını genişletip etkilerini incelemek amaçlanmış ve duruşla ilgili vestibüler duyumların gıda tadı algılarını etkilediği, ayakta dururken yemek yiyen tüketiciler hoş ve lezzetli yiyecek ve içeceklerin tadını daha az olumlu yönde değerlendirmişler ve daha az tüketmişlerdir. Ayrıca tüketicinin duruşunun tat algısı üzerinde etkisi olduğu sonucuna saptanmıştır. Satti vd. 2019'da yapmış oldukları 
araştırmada restoranlarda uygulanan duyusal pazarlama ile hizmet kalitesi arasındaki ilişkinin müşteri memnuniyeti üzerindeki rolünü incelemek amaçlanmış ve gençlerin duyusal uyarıcılara daha fazla ilgi duyduğu, duyusal pazarlama bileşenleri ile hizmet kalitesinin birleştiği restoranların daha büyüleyici olduğu ve bu tip restoranların müşterilerde tekrar gelme isteği oluşturduğu sonuçlarına ulaşılmıştır. Ayrıca araştırmada tüketicilerin eğitim durumlarının restoran beğenilerinde önemli etkiye sahip olduğu ve eğitim düzeyleri yüksek olan tüketicilerin duyusal pazarlama bileşenlerini kullanan restoranlara daha fazla ilgi duyduğu sonucuna saptanmıştır. Jang ve Lee'nin 2019'da yapmış oldukları araştırmada duyusal pazarlama görme, koku, ses, tat ve dokunma bileşenlerinin sürdürülebilir müşteri arasındaki ilişkiyi incelemek amaçlanmış ve görme ile hâkimiyet arasında, ses ile uyarılma, tat ile hâkimiyet, tat ile uyarılma, dokunma ile hâkimiyet, dokunma ile uyarılma arasında istatiksel olarak anlamlı olduğu sonucuna ulaşılmıştır. Ayrıca araştırmada zevk ve akışın davranışsal niyetler üzerinde olumlu bir etkiye sahip olduğu sonucuna saptanmıştır. Yoganathana vd. 2019'da yapmış oldukları araştırmada görsel, işitsel ve dokunsal duyuların çevrimiçi ortama uyarılmasına odaklanılmış ve çevrimiçi dokunma hissini teşvik etmek için dolaylı bir yaklaşım hazırlanmaya çalışılmıştır. Araştırmada iki model belirlenmiştir. For consumers with high (ALTBIO) görsel ve işitsel uyarıcıların tüketicide algılanan marka etiğine aracılık ettiği, Need for Touch (NfT) ise dokunsal uyarıcılarda sadece Nft yüksek olan tüketiciler için önemli bir etkiye sahip olduğu sonuçlarına ulaşılmıştır. Lv vd. 2020'de yapmış oldukları araştırmada duyusal izlenimlerin hedef sadakat üzerinde oynadığı rolü incelemek amaçlanmış ve çevrim içi olumlu duyusal izlenimlerin sadakat üzerinde olumlu bir etkiye sahipken olumsuz duyusal izlenimlerin sadakat üzerinde olumsuz bir etkiye sahip olduğu ve duyusal izlenimlerin sadakat üzerinde ayırt edilebilir bir güce sahip olduğu sonuçlarına ulaşılmıştır. Büdün ve Ertürk'ün 2020'de yapmış oldukları araştırmada duyusal markalamada beş duyunun tüketici tutumları üzerindeki etkisini incelemek amaçlanmış ve bilişsel yönlü tutumların tüketicilerin tercihleri üzerinde daha çok etkili olduğu ve duygusal ile davranışsal yönlü tutumlarında da önemli bir etkiye sahip olduğu sonuçlarına ulaşılmıştır. Sarıbaş ve Demir'in 2020'de yapmış oldukları araştırmada turizm araştırmalarında çeşitli alanlarda kullanılan duyuların kullanımı üzerine bir araştırma yapmak amaçlanmış ve duyuların turizmde kullanılmadığı ve duyusal pazarlama, duyusal markalaşma, duyusal turizm deneyimi ile turizmde duyu kullanımı gibi kavramlar kullanılarak yeni yaklaşımların geliştirildiği sonuçlarına ulaşılmıştır. Balıkoğlu vd. 2020'de yapmış oldukları araştırmada turistlerin duyusal deneyim memnuniyeti ve yöresel yiyecek 
deneyimi arasındaki ilişkinin incelenmesi ve daha sonra bu faktörlerin daha sonraki yıllarda tüketicilerin davranışlarında nasıl bir etkiye sahip olduğunu incelemek amaçlanmış ve baklavaya ilişkin duyusal deneyimden memnun olan turistlerin yöresel yiyecek deneyimlerinin de olumlu yönde olduğu ve bu deneyimlerin tüketiciler üzerinde tekrar satın alma, diğer tüketicilere tavsiyede bulunma davranışları ile pozitif yönlü bir etkiye sahip olduğu sonuçlarına ulaşılmıştır.

Tez Çalışmaları:

Imram'ın 1999'da yapmış olduğu yüksek lisans tez çalışmasında duyusal pazarlama uygulamalarının müşteri üzerindeki etkisini incelemek amaçlanmış ve renk ile görünüm özelliklerinin katılımcılar tarafından diğer dış etkenlerden daha çok önemli olduğu ve tatılarda kullanılan renkler ile görünüm özelliklerinin müşterilerin kalite algıları ve satın alma güdüleri üzerinde etkili olduğu sonuçlarına ulaşıımıştır. Thakkar'ın 2008'de yapmış olduğu doktora tez çalışmasında alışveriş merkezi ortamlarının ve internet alışveriş ortamlarının tüketici kararlarına etkilerini incelemek amaçlanmış ve tüketicilerin internet üzerinden değerlendirmeler yaparken bir ürünün duyusal nitelikler üzerindeki üstünlüğünü değerlendiremedikleri, ürünleri daha çok olumsuz yönde değerlendirdikleri fakat ürünü fiziksel mağazalarda ise daha çok olumlu yönde değerlendirmeler yaptıkları sonuçlarına ulaşılmıştır. Ayrıca bu sonuçlar doğrultusunda dokunma hissinin tüketicilerin satın alma kararlarında etkili olduğu sonucu saptanmıştır. Hwang'ın 2009'da yapmış olduğu yüksek lisans tez çalışmasında izleyicilerin canlı spor etkinlikleri ve yerel destinasyonlar arasındaki duyusal görüntü algısını ölçebilmek için güvenilir ve geçerli bir ölçek geliştirmek amaçlanmıştır. Araştırmacı, araştırma sonucunda beş faktörlü (görüntü, ses, koku, yiyecek ve içecek uyumlu) bir ölçek geliştirmiştir. Ayrıca araştırma sonucunda duyusal kavramsallaştırmanın sporseverlerin zihninde görüntü uyumunun mümkün olduğu sonucu saptanmıştır. Elder'in 2011'de yapmış olduğu doktora tez çalışmasında görsel ve sözel bilginin insan üzerindeki etkisini araştırmak amaçlanmış ve bilişin hem kasıtlı hem de daha otomatik seviyelerde duyusal algıları etkilediği ve tüketici davranışları üzerinde büyük bir etkiye sahip olduğu sonuçlarına ulaşılmıştır. Ayrıca duyusal uyarıcıların kullanıldığı reklamın etkisinin standart satın alma öncesi tutum ve niyetlerin çok ötesine geçtiği ve gerçek tüketimi etkilediği sonucuna da ulaşımıştır. Bu sonuçlar doğrultusunda araştırmacı reklamların görsel uyaranların çok ince manipülasyonları yoluyla niyetlerimizi değiştirebileceğini sonucunu ifade etmiştir. Agapito'un 2013'te yapmış olduğu doktora tez çalışmasında kırsal kesimlerde uygulanabilecek duyusal pazarlama boyutlarının turist 
deneyimleri üzerindeki etkisi incelenmiştir. Araştırmada bireylerin olumlu ve unutulmaz bir turist deneyimi yaşamalarında duyusal boyutun önemli bir etkiye sahip olduğu sonucuna ulaşılmıştır. Ayrıca kırsal kesimde turistik deneyimlerin pazarlanmasında duyusal uyaranların kullanılması bu kırsal kesimlerin turistler tarafından daha fazla tercih etmelerin üzerinde de olumlu etkiye sahip olduğu sonucu saptanmıştır. Rodrigues'in 2014'te yapmış oldukları doktora tez çalışmasında Duyusal boyutların marka duygusallığı ve marka değeri üzerindeki etkisini incelemek amaçlanmış ve marka duygusallığı için duyusal stratejilerin yalnızca değer üretme sürecinde kullanılması gerektiği, marka duygusalığı, bir yapı olarak, hizmet sunumunun odak noktasında marka değerinin önemli bir itici gücü olduğu ve marka deneyimleri ve dolaylı olarak CBBE marka duygusalığını doğrudan etkilediği sonuçlarına ulaşılmıştır. Neema'nın 2015'te yapmış olduğu doktora tez çalışmasında müşterilerin fiziksel ortamın kalitesini nasıl algıladıklarını belirlemek ve duyusal pazarlamanın müşteri sadakati üzerindeki etkisini incelemek amaçlanmış ve müzik, aroma, tat ve konsept, müşterilerde oteli yeniden ziyaret etmek için duygusal/psikolojik davranışlar geliştiren kolektif bir ortam yaratığı, restoranın müşterilerine renklendirme gibi sunduğu görsel efektlerin, aydınlatma ve dekorun müşterilerin kendilerini özel hissettirdiği, hafızalarında bir iz bıraktığı, otel ve restoran hakkındaki düşüncelerinde büyük bir etkiye sahip olduğu ve duyusal pazarlama boyutlarının (kokusal, görsel, işitsel, dokunsal ve tatsal) müşteri sadakati üzerinde pozitif bir etkiye sahip olduğu sonuçlarına ulaşılmıştır. Cesim'in 2015'te yapmış olduğu yüksek lisans tez çalışmasında yeni bir kavram olan psikonörobiyokimya'yı açıklamak ve yiyecek ve içecek işletmeleri pazarlamasında etkisi olan psikonörobiyokimyasal faktörlerin tüketici davranışları üzerindeki etkisini incelemek amaçlanmış ve yiyecek ve içecek işletmelerinin hem tüketicilerin memnuniyetlerini sağlayabilecek hem de işletmenin amacına uygun menü oluşturabilecekleri yiyecek ve içecek işletmeleri pazarlanmasında psikonörobiyokimya yaklaşımı tablosu oluşturulmuştur. Ayrıca araştırma sonucunda nöropazarlama bilimi çeşitli araçlar kullanarak ve kendine özgü tekniklerle satın alma kararını ve tüketici davranışlarını etkileyebildiği sonucu saptanmıştır. Krey'in 2016'da yapmış oldukları doktora tez çalışmasında duyusal pazarlama boyutlarının farklı ortamlarda ve farklı sensör stimülasyon seviyelerinde tüketicileri nasıl etkileyebileceğini ve insanların çevredeki duyusal uyarıcılara nasıl tepkiler vereceğini incelemek amaçlanmış ve tüketiciler yüksek veya düşük yoğunluklu duyu ortamlarında algısal ve bilişsel görevleri yerine getirdikleri ve farklı ortamların farklı faydalar sağladığı sonuçlarına ulaşılmıştır. Ayrıca araştırmada katılımcıları yüksek veya düşük duyum ihtiyacı olarak 


\section{Ali Elibol}

sınıflandırmak için yeni bir ölçek geliştirilmiştir. Yozukmaz'ın 2016'da yapmış olduğu yüksek lisans tez çalışmasında Muğla ili Bodrum ilçesinde yer alan beş yıldızı otellerin duyusal pazarlama uygulamalarını incelemek amaçlanmış ve araştırma dâhilindeki otellerin misafirlerin duyularını etkileyen stratejilere başvurdukları, uyguladıkları duyusal pazarlama stratejilerinden görselliğin olduğu ve bu stratejiyi uygulayan otellerin bu pazarlama stratejisine önemli ölçüde bütçe ayırdığı sonuçlarına ulaşımıştır. Demiray'ın 2016'da yapmış olduğu yüksek lisans tez çalışmasında duyusal öğelerden olan ses, renk ve ışık faktörlerinin tüketicilerin satın alma davranışları ve kalite algıları üzerindeki etkilerini amaçlanmış ve mağaza atmosferi oluşturulurken duyusal öğelerin kullanılması tüketicilerin kalite algısını, satın alma davranışlarını etkilediği ve özellikle müziğin farklı tarzlarda ve farklı tempolarda kullanılması tüketicilerin davranışları üzerinde etkili olduğu sonuçlarına ulaşılmıştır. Peker'in 2017'de yapmış olduğu yüksek lisans tez çalışmasında duyusal markalamanın tüketicilerin marka algılarındaki rolünü ve demografik faktörler üzerindeki farklılıkları incelemek amaçlanmış ve duyusal markalamanın tüketicilerde pozitif yönde bir tutum oluşturduğu ve gruplar arası anlamlı bir farkın olduğu sonuçlarına ulaşılmıştır. Pramudya'ın 2018'de yapmış olduğu yüksek lisans tez çalışmasında el hissi dokunma ipuçlarının duyusal algı ve duygusal tepkiler üzerindeki etkilerini incelemek amaçlanmış ve daha yüksek sıcaklıktaki içecekler soğuk havalarda olumlu duygularla karakterize edildiği, el hissi dokunuşu ve tat ipuçları arasında da pozitif bir iliş̧inin olduğu sonucuna ulaşılmıştır. Araştırmada katılımcılar paslanmaz çelik malzemenin ekşi tat, keten liftlerinden yapılmış malzemenin tuz ile ilişkilendirildiği sonuçlarına da ulaşılmıştır. Ayrıca araştırmada daha kalın ve daha kaba malzemelerin olumsuz duygularla pozitif olarak ilişkili olduğu, ince ve pürüzsüz malzemelerin yüksek uyarılma ve olumlu duygular ile pozitif yönde ilişkili olduğu, sunulan kahvenin (havlu, keten veya paslanmaz çelik) karton (kontrol) ile karşılaştırıldığında hem duygular hem de duyusal özellikler açısından farklı algılandığı ve dokunmatik ipuçlarının ürün değerlendirmesinde önemli olduğu sonuçları saptanmıştır. Onar'ın 2018'de yapmış olduğu yüksek lisans tez çalışmasında perakende sektörü mağaza yöneticileri ile görüşülerek duyusal pazarlama bileşenlerinin ülkemizdeki uygulamalarını ortaya koymak amaçlanmış ve araştırmanın yapıldığı on mağazadan bir kısmının bilinçli, bir kısmının ise bilinçsiz bir şekilde duyusal pazarlama stratejisini uyguladığı, duyusal pazarlama stratejilerinin müşteri üzerinde pozitif yönlü bir ilişkiye sahip olduğu ve duyusal pazarlama stratejilerinin müşteri memnuniyeti üzerinde oldukça önemli olduğu sonuçlarına ulaşılmıştır. Ayrıca araştırmada müşterilerin satın alma 
esnasında duyusal pazarlama stratejilerinden de etkilendiği sonucuna ulaşılmıştır. Grıguer'in 2018'de yapmış olduğu yüksek lisans tez çalışmasında duyusal pazarlama stratejilerinin tüketici davranışları üzerindeki etkisini incelemek amaçlanmış ve duyuların tüketici davranışı üzerindeki pozitif yönlü bir etkiye sahip olduğu sonucuna ulaşılmıştır. Ayrıca araştırmada duyusal uyarıcıların tüketicinin duygusal, bilişsel ve davranışsal tepkilerini etkilediği ve bireysel değişkenlere bağlı olarak koku ve müzik gibi uyarıcıların satın alma davranışı üzerinde etkili olduğu sonuçları saptanmıştır. Mateyev'in 2018'de yapmış olduğu yüksek lisans tez çalışmasında tekstil sektöründe faaliyet gösteren mağazaların kullandıkları duyusal pazarlama stratejilerinin (duyma, koku, görme ve dokunma) tüketicilerin üzerindeki etkilerini incelemek amaçlanmış ve bir mağazada çalınan müziğin türü, ritim, ses düzeyi, hoş kokuları, çalışanların dış görünümü, mağazanın düzeni ve estetiği tüketicilerin davranışlarını ve mağaza tercihlerini etkilediği, dokunma duyusunun gruplara göre istatistiksel olarak anlamlı bir farklılık olduğu ve koklama duyusunun gruplara göre istatiksel olarak anlamlı bir farklılık göstermezken duyma duyusunun gruplara göre anlamlı bir farklıı̆ı̆ın olduğu sonuçlarına ulaşılmıştır. Çakaröz'ün 2018'de yapmış olduğu doktora tez çalışmasında duyusal markalama uyaranlarının hızlı tüketim mallarını satın alan tüketicilerin yeniden satın alma kararı üzerindeki etkisini incelemek amaçlanmış ve hızlı tüketim malların çok satın aldıkları ürünler; yiyecek kategorisinde çikolata, içecek kategorisinde gazlı içecekler, kişisel bakım kategorisinde sabun ve temizlik kategorisinde çamaşır deterjanı olduğu sonucuna ulaşılmıştır. Ayrıca araştırmada hızı tüketim mallarından kişisel bakım grubunda en çok dokunsal ve kokusal uyarıcıların, yiyecek grubunda en çok kokusal ve tatsal uyarıcıların, temizlik grubunda en çok kokusal ve görsel uyarıcıların ve içecek grubunda ise en çok işitsel ve kokusal uyarıcıların tüketicileri etkilediği sonuçları saptanmıştır. Ek olarak araştırmada dokunma, görme, işitme, koklama ve tatma duyularının her birinin ayrı ayrı tüketicilerin hızlı tüketim mal gruplarını yeniden satın alma kararlarında olumlu yönde etkili olduğu sonucu saptanmıştır. Doğan'ın 2018'de yapmış olduğu yüksek lisans tez çalışmasında English Home ve Özdilek firmalarının duyusal pazarlama uygulamalarını incelemek amaçlanmış ve duyusal pazarlamanın, marka sadakati yaratmada üzerinde güçlü bir etkiye sahip olduğu sonucuna ulaşılmıştır. Kahvecioğlu'nun 2018'de yapmış olduğu yüksek lisans tez çalışmasında Bodrum'da faaliyet gösteren beş yıldızlı otellerde uygulanan duyusal pazarlama stratejilerinin müşteri sadakati üzerindeki etkisini incelemek amaçlanmış ve otel işletmelerinde uygulanan dokunsal, görsel, işitsel, tatsal ve kokusal duyusal 
pazarlama boyutlarının müşteri sadakati üzerinde olumlu yönde bir etkiye sahip olduğu sonucuna ulaşılmıştır. Kamaran'ın 2019'da yapmış olduğu yüksek lisans tez çalışmasında duyusal pazarlama stratejilerinin müşterilerin karar verme süreçleri üzerindeki etkisini incelemek amaçlanmış ve sürükleyicilik faktörünün en önemli duygusal olay olduğu, marka tecrübesinin ise duygusal olaylar üzerinde önemli etkiye sahip olduğu sonuçlarına ulaşılmıştır. Ayrıca araştırmada marka deneyiminin marka kişiliği üzerinde ve marka kişiliğinin marka bilinirliği üzerinde etkili olduğu sonucu saptanmıştır. Yeliz'in 2019'da yapmış olduğu yüksek lisans tez çalışmasında duyusal markalama stratejilerinden koku duyusunun cinsiyete bağlı olarak kalite, fiyat ve satın alma rızasını incelemek amaçlanmış ve koku markalamanın kadın ve erkek tüketicilerin fiyat, kalite ve satın alma rızası üzerinde etkiye sahip olduğu sonucuna ulaşılmıştır. Ayrıca araştırmada koku duyusunun fiyat, kalite ve satın alma davranışı üzerinde kadınlarda pozitif yönde erkekler de ise negatif yönde istatistiki olarak anlamlı olduğu sonucu saptanmıştır. Çanakçı'ın 2019'da yapmış olduğu yüksek lisans tez çalışmasında nöromarketing'in (duyusal pazarlama) kalite, toplam kalite alanında kullanılması durumunda kalite algısında ortaya çıkan kazanımların incelenmesi amaçlanmış ve kalitenin tüketicinin beklenti ve isteklerini karşıladığı sonucuna ulaşılmıştır. Ayrıca araştırmada ürünlerin fiyatlarının yüksek olması tüketicilerin kalite algılarında pozitif bir etkiye sahip olduğu, bilinçaltı testinde kola içeceğinin tadından çok markanın kalite algılarını etkilediği ve çorba deneyinde ise firmanın logosunun ve ambalaj şeklinin tüketicilerin dikkatini çekmediği ve satın alma isteği oluşturmadığı sonuçları da saptanmıştır. Atıcı'nın 2019'da yapmış olduğu yüksek lisans tez çalışmasında beş boyutlu (tat alma, koku, görme, dokunma ve işitme) bir deneyim oluşturarak beş duyunun marka değeri üzerindeki etkisini incelemek amaçlanmış ve Coca-Cola'nın duyusal pazarlamada beş duyusal pazarlamayı etkili kullanarak üstün bir marka değeri yarattığı sonucuna ulaşılmıştır. Kalay'ın 2019'da yapmış olduğu yüksek lisans tez çalışmasında duyusal pazarlamanın; tüketici satın alma tercihleri üzerindeki etkisini ve demografik değişkenler ile olan ilişkisini incelemek amaçlanmış ve tüketicilerin cinsiyet, yaş, gelir ve eğitim durumlarının duyusal pazarlama faaliyetlerinden etkilenme düzeyleri arasında farlılık olduğu sonucuna ulaşılmıştır. Aydemir'in 2019'da yapmış olduğu yüksek lisans tez çalışmasında hava yolu işletmelerinin uygulamış olduğu duyusal pazarlama stratejileri ile tüketici kazanımı arasındaki ilişkiyi incelemek amaçlanmış ve duyusal pazarlama stratejilerinin tüketici kazanımı üzerinde etkili olduğu sonucuna ulaşılmıştır. Ayrıca araştırmada Pegasus ve Türk Hava Yolları'nın uygulamış olduğu duyusal pazarlama stratejileri müşterileri tutma 
sonuçlarında farklılık gösterdiği bu nedenle Türk Hava Yolları'nın müşterilerinin genellikle şirkete sadık olduğunu fakat Pegasus müşterilerinin şirkete sadık olmadıkları sonucu saptanmıştır. Öztel'in 2019'da yapmış olduğu yüksek lisans tez çalışmasında duygusal pazarlamada slogan kullanımının önemini incelemek amaçlanmış ve duygusal bağ oluşturma sürecinde, slogan mesajının hedef kitleye ulaşmasında model kullanımının önemli olduğu sonucuna ulaşılmıştır. Ayrıca araştırmada sloganların marka inşasında önemli unsurlardan bir tanesi olduğu sonucu saptanmıştır.

\section{MÜŞTERİ SADAKATİ KAVRAMI VE YAKLAŞIMLARI}

Teknolojinin gelişmesi pazarlama alanında müşterilerin ürün veya hizmetlere daha kolay bir şekilde ulaşmasına ve ürün ve hizmetleri karşılaştırabilmesine imkân vermesi işletmeler arasında yoğun bir rekabet ortamını ortaya çıkarmıştır. Ortaya çıkan bu yoğun rekabet, işletmeleri pazarda yeni stratejiler uygulamaya yöneltmiş ve böylece pazarlama dünyasında müşteri sadakati kavramı önem kazanmaya başlamıştır. Özellikle hizmet sunan sektörlerde müşteri sadakati kavramı büyük öneme sahiptir (Pullman ve Gross, 2004: 558-559). Bu nedenle önem kazanan müşteri sadakati üzerine literatürde birçok araştırmaya rastlamak mümkündür. Literatürde yer alan bu araştırmalar incelendiğinde müşteri sadakatinin temelini müşterinin duyduğu derin bir bağlılık oluşturmaktadır. Bu derin bağlılık herhangi bir işletmeye, mal ve hizmete ortama (atmosfere) veya satıcıya karşı olabilmektedir. Müşteri sadakati üzerine literatürde yer alan bazı tanımlar ise;

- Oliver müşteri sadakatini müşterinin bir ürün veya hizmeti gelecekte de sürekli satın alması ya da müşterinin tekrar o ürün veya hizmeti satın almak için derin bağlılık duyması olarak ifade etmiştir. (Oliver, 1999: 34).

- Odabaşı ve Barış, müşteri sadakatini müşterilerin gereksinimlerini karşılamak için aynı işletmeyi veya markayı tercih etme arzusu olarak ifade etmektedirler (Odabaşı ve Barış, 2010: 20).

- İslamoğlu ve Altunışık ise müşteri sadakatini bir işletmeden sürekli ürün veya hizmet alma eğiliminde bulunma arzusu ya da devamlı aynı markayı satın alma isteğinde bulunulması olarak ifade etmektedirler (İslamoğlu ve Altunışık, 2013: 5).

- Hassan ve Iqbal'e göre müşteri sadakati müşterinin herhangi bir markaya ya da işletmeye olan düşkünlüğü olarak ifade etmektedirler (Hassan ve Iqbal, 2016: 729).

- Bayuk ve Küçük'e göre müşteri sadakati müşterinin başka alternatiflerinde mevcut olduğu bir ortamda, belirli bir işletmeye 


\section{Ali Elibol}

veya satıcıya yönelik içten ve samimi duyduğu istek olarak ifade etmişlerdir (Bayuk ve Küçük, 2007: 287).

- Özer ve Günaydın'a göre müşteri sadakati müşterilerin herhangi bir işletmeye karşı duydukları olumlu duyguları, mal veya hizmeti yeniden satın alma davranışı ve işletmeyi çevresindeki kişilere önermesi eğilimi olarak ifade etmişlerdir (Özer ve Günaydın, 2010: 132).

Günümüzde müşterileri potansiyel müşteriler haline getirebilmek için müşteri sadakati işletmeler açısından son derece önemlidir. Bu nedenle günümüzde müşterilerin beklentilerini ve gereksinimlerini yakından takip eden işletmeler müşteriler ile birebir ilişkiler kurmanın müşterilerde sadakat duygusunu oluşturma noktasında büyük bir önem arz ettiğini bildiklerinden dolayı müşterilerin mal ve hizmetleri tekrar satın alınmasında büyük öneme sahip olan bu sadakat duygusunu oluşturabilmek için müşteri profillerine göre stratejiler oluşturmaktadırlar (Odabaşı, 2017: 15). İşletmelerin müşterilerini memnun etmek ve müşterilerinde sadakat duygusunu oluşturabilmek için uyguladıkları birtakım stratejiler ise; müşteri profilini iyi belirlemek ve tanımak, müşteri ile yakın ilişkilerde bulunmak, müşteriyi iyi dinlemek ve anlamak, müşterilerden gelen geri bildirimlere önem vermek ve beklemeden hemen cevap vermek, eleştirilerden, şikâyetlerden, öneri veya tavsiyelerden yeni stratejiler geliştirmek, müşterilerin gereksinimlerini karşılayan mal ya da hizmet tasarımları geliştirmek ve sadece satışa odaklanmak değil satış sonrası hizmetlere de odaklanmaktır (Kanat, 2003: 63-71).

Sadakatin derecesi her müşteride aynı değildir. Çünkü müşteri sadakati birbirini takip eden ve birbirini tetikleyen aşamalar silsilesidir. Bu nedenle bir müşteri sürecin farklı bir aşamasında iken diğer bir müşteri ise diğer bir aşamasında olabilir (Knox, 1998: 733). Bu süreçler davranışsal, tutumsal ve karma süreçler veya yaklaşımlardır. Davranışsal sadakat yaklaşımın temelinde müşterinin satın alma eylemini tekrar etmesidir (Altıntaş, 2000: 32). Bu nedenle davranışsal sadakat yaklaşımı bir müşterinin satın aldığı markayı yeniden satın almaya yönelik sergilediği davranış ya da ilgisidir (Uncles vd., 2003: 16). Tutumsal müşteri sadakatinin temelinde ise müşterinin bir işletmeye karşı bağlı olmasıdır. Bu yaklaşımda müşteri işletmeden alışveriş yapmasa bile işletmeye karşı sadık kalarak işletmeyi çevresindeki kişilere tavsiye etmesi söz konusudur (Tuğrul, 2009: 9). Son yaklaşım olan karma müşteri sadakati yaklaşımın temelinde ise, davranışsal müşteri sadakati ile tutumsal müşteri sadakatini birbirine entegre ederek hem müşterinin işletmenin mal veya hizmetlerini 


\section{Ali Elibol}

yeniden satın alma eğilimini tekrar etmesi hem de işletmeye karşı oluşturduğu bağlılık eğilimi ile işletmeyi çevresindeki kişilere tavsiye etmesi yer almaktadır (Çatı ve Koçoğlu, 2008: 172). Bu üç yaklaşım açısından müşteri sadakat düzeyleri ise dört farklı düzeyde karşımıza çıkmaktadır. Bu düzeyler Şekil 2'de verilmiştir.

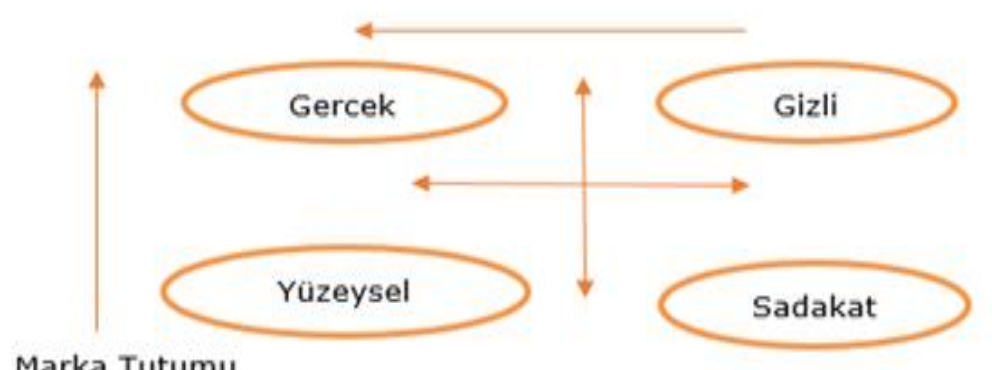

Şekil 2. Müşteri Sadakati Düzeyleri (Dick, A. S. \& Basu, K. 1994)

Şekil 2'de gerçek sadakat, müşteride oluşan en yüksek sadakat düzeyidir. Günümüzdeki işletmeler müşterilerini ellerinde tutabilmek ve müşterilerinde güçlü bir sadakat duygusunu oluşturabilmek istedikleri en ideal düzeydir. Bu düzeydeki amaç müşterilerin işletmenin diğer rakip işletmelere karşı üstünlüklerini ve farklılıklarını algılamalarını sağlayarak müşterilerin işletmeye karşı tutumlarını olumlu düzeyde artırabilmektir. Gizli sadakat düzeyi ise müşterilerin işletmeye karşı olumlu bir eğilim içerisinde oldukları fakat sürekli satın alma eğilimi içerisinde olmadıklarıdır. Müşterilerin işletmeye karşı ilgisiz kaldıkları ve herhangi bir eylemde bulunmadıkları düzey ise yüzeysel sadakattir. Bu düzeydeki müşteriler çevresindeki kişilerin tavsiyelerine veya çıkarlarına göre zaman zaman işletmelere sadık olup işletmelerden mal veya hizmet satın alabildikleri gibi kolaylıkla rakiplerin i tercih ederek onların mal veya hizmetlerini de satın alma eğilimi gösterebilmektedirler. Son düzey ise, müşterilerin işletmenin mal veya hizmetlerine karşı satın alma davranışlarının en düşük olduğu sadakatin olmadığı düzeydir (Dick ve Basu, 1994: 102).

\section{YÖNTEM}

\section{Araştırmanın Amacı}

Müşterilerin istek ve ihtiyaçlarının soyut varlıklar ile giderildiği turizm sektörü müşteri odaklı olması nedeniyle beş duyunun önem arz ettiği bir sektördür. Bu nedenle günümüzdeki konaklama işletmeleri müşterilerinde sadakat duygusunu oluşturabilmek için duyusal pazarlama stratejilerini en etkili biçimde kullanmaya çalışmaktadır. Çünkü yerli veya yabancı müşterilerin tatil sürelerinde en çok vakit geçirdikleri yerler konakladıkları 
oteller olduğundan dolayı otel işletmeleri yerli veya yabancı turistlerin beş duyusuna da hitap ederek işletmeleri ile müşteriler arasında bir bağın oluşmasını sağlayabilmek için çaba sarf etmektedirler.

Günümüzde Türkiye'nin Maldivler'i olarak Türkiye turizminde marka bir destinasyon haline gelen Burdur İl'ine bağlı Yeşilova ilçesinde bulunan Salda Gölü'ne yaz aylarında yoğun bir ziyaretçi akışı olmaktadır (Elibol, 2020: 187). Bu nedenle bu araştırmanın amacı Burdur ili Yeşilova ilçesinde yer alan Salda Gölü'ne gelen turistler üzerinde duyusal pazarlama uygulamalarının müşteri sadakati üzerindeki etkisini araştırmaktır. Bu kapsam doğrultusunda Salda Gölü'ne gelen 258 yerli turist ile yüz yüze görüşülerek nicel araştırmalarda kullanılan anket tekniğiyle veriler kolayda örnekleme yöntemi ile toplanmıştır. Araştırmaya başlamadan önce literatür taraması yapılmış ve ulaşılabilen çalışmalar incelenerek araştırmanın yöntemi belirlenmiştir. Daha sonra araştırmada kullanılan anket formu incelenen bu araştırmalarda kullanılan anket formlarından yararlanılarak oluşturulmuştur. Araştırma kapsamı ve amacı doğrultusunda oluşturulan anket formu üç bölümden oluşmaktadır. Bu bölümlerden birincisinde dokunsal, görsel, işitsel, tatsal ve kokusal duyusal pazarlamanın alt boyutlarını ölçmek için toplam 26 önerme yer almaktadır. İkinci bölümde ise müşteri sadakatini ölçmek için 6 önerme yer almaktadır. Son bölümünde ise katılımcıların demografik özelliklerini belirlemek amacı ile 6 önermenin yer aldığı demografik bilgiler bölümü bulunmaktadır. Hazırlanan bu anket formu sayesinde elde edilen veriler sosyal bilimlerde kullanılan SPSS 22.00 programında analiz edilmiş ve analiz soncunda duyusal pazarlama uygulamalarına ilişkin alt boyutlar olan dokunsal, görsel, işitsel, tatsal ve kokusal boyutlar ile müşteri sadakati önermeleri arasında ve müşteri sadakati ile duyusal pazarlama uygulamaları arasında pozitif yönde anlamlı bir ilişki olduğu sonucuna ulaşılmıştır. Elde edilen bu sonuçlar kapsamında günümüzdeki konaklama işletmeleri kendilerine özgü oluşturdukları koku, tat, tasarım gibi müşterilerin beş duyu organlarına hitap edecek duyusal pazarlama stratejilerini etkin bir şekilde uygularsa hem rakipleri karşısında üstünlük kuracaklar hem de işletmelerini tercih eden müşterilerinin sadakatini kazanmış olacaklardır.

\section{Araştırmanın Kapsamı ve Kısıtları}

Duyusal pazarlama boyutlarının müşterilerin tercihleri müşteri sadakati üzerindeki etkilerini ölçmeye yönelik olan bu çalışmanın ana kütlesini Batı Akdeniz bölgesinde yer alan Burdur İli 'ne ziyarete gelen yerli turistler oluşturmaktadır. Maliyet ve zaman kısıtlamalarının yanında 


\section{Ali Elibol}

günümüzdeki Covid-19 salgınından dolayı Burdur İli genelinde bir araştırma yapılamamıştır.

\section{Araştırma Modeli}

Günümüzde duyusal pazarlama uygulamalarına yönelik birçok niceliksel çalışma yapılmaktadır. Yapılan bu çalışmalarda araştırmacılar farklı yöntemler kullanmakta ve farklı sektörler üzerinde duyusal pazarlama uygulamalarının müşteriler üzerinde etkilerini belirlemeye çalışmışlardır. Bu araştırmada da otel işletmelerinde farklı duyulara hitap eden duyusal pazarlama uygulamalarının müşteri sadakati üzerindeki etkisi belirlenmeye çalışılmıştır. Araştırmanın modelinde çalışmanın bağımlı değişkeni müşteri sadakati olup bağımsız değişkenler duyusal pazarlama ve duyusal pazarlamanın alt boyutlarıdır. Ayrıca araştırmada araştırmaya katılan katılımcıların sosyo-demografik özelliklerin belirlenmesi amacıyla cinsiyet, medeni ve eğitim durumları, aylık gelir düzeyi, tatil yapma amacı ile yaş grupları değişkenleri de yer almaktadır. Araştırmada yer alan dokunsal, görsel, işitsel, tatsal ve kokusal boyut bağımsız değişkenlerde yer alan yirmi altı önermenin otel işletmelerinde duyusal pazarlama uygulamalarının müşteri sadakati üzerindeki etkisini ortaya çıkarması beklenmektedir (Tosun ve Elmasoğlu, 2015: 98; Kara ve Temiz, 2018: 466, Kahveci, 2018: 76).

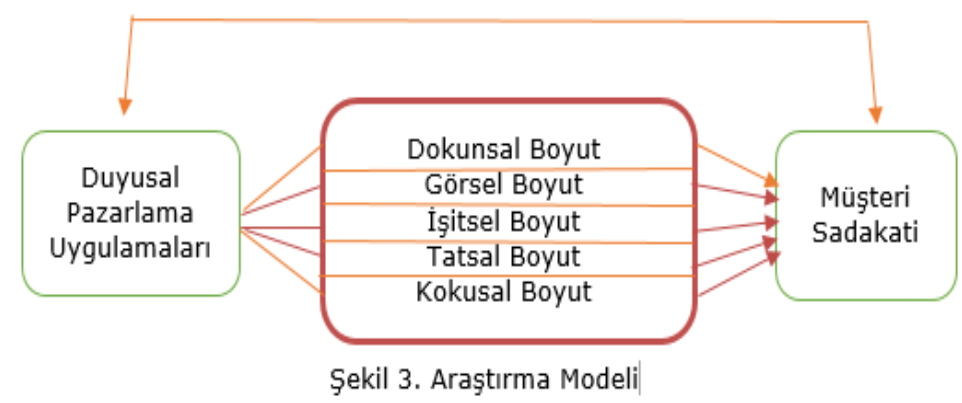

\section{Araştırmanın Hipotezleri}

Araştırma modeli dikkate alınarak, araştırmanın amacına uygun araştırmada test edilmek üzere duyusal pazarlama uygulamalarına dayalı olarak on üç tane hipotezler aşağıdaki gibi geliştirilmiştir. Hipotezler geliştirilirken Yozukmaz'ın 2016'daki, Kahvecioğlu'nun 2018'deki yapmış oldukları çalışmalardan yararlanılmıştır. Bu hipotezler:

- $\mathrm{H}_{1}$ Konaklama işletmelerinde duyusal pazarlama uygulamaları müşteri sadakati üzerinde anlamlı bir etkiye sahiptir. 
- $\mathrm{H}_{2}$ Konaklama işletmelerinde dokunsal boyut müşteri sadakati üzerinde anlamlı bir etkiye sahiptir.

- $\mathrm{H}_{3}$ Konaklama işletmelerinde görsellik boyut müşteri sadakati üzerinde anlamlı bir etkiye sahiptir.

- $\mathrm{H}_{4}$ Konaklama işletmelerinde işitsel boyut müşteri sadakati üzerinde anlamlı bir etkiye sahiptir.

- $\mathrm{H}_{5}$ Konaklama işletmelerinde tatsal boyut müşteri sadakati üzerinde anlamlı bir etkiye sahiptir.

- $\mathrm{H}_{6}$ Konaklama işletmelerinde kokusal boyut müşteri sadakati üzerinde anlamlı bir etkiye sahiptir.

- $\mathrm{H}_{7}$ Katılımcıların duyusal pazarlama uygulamalarına ilişkin değerlendirmeleri ile cinsiyetleri arasında farklılık bulunmaktadır.

- $\mathrm{H}_{8}$ Katılımcıların duyusal pazarlama uygulamalarına ilişkin değerlendirmeleri medeni durumlarına göre farklılık göstermektedir.

- $\mathrm{H}_{9}$ Katılımcıların sadakate ilişkin değerlendirmeleri cinsiyete göre farklılık göstermektedir.

- $\mathrm{H}_{10}$ Katılımcıların sadakate ilişkin değerlendirmeleri ile medeni durumları arasında farklılık bulunmaktadır.

- $\mathrm{H}_{11}$ Katılımcıların sadakate ilişkin değerlendirmeleri ile eğitim duruları arasında farklılık bulunmaktadır.

- $\mathrm{H}_{12}$ Katılımcıların sadakate ilişkin değerlendirmeleri ile yaş grupları arasında farklılık bulunmaktadır.

- $\mathrm{H}_{13}$ Katılımcıların sadakate ilişkin değerlendirmeleri ile tatil yapma amaçları arasında farklılık bulunmaktadır.

\section{Veri Toplama Yöntemi}

Araştırmanın ana kütlesi Batı Akdeniz bölgesinde yer alan Burdur İli'ne ziyarete gelen yerli turistler oluşturmaktadır. Araştırmada evrenini oluşturan katılımcıların özellikleri benzer ve homojen olması durumunda olasılıklı olmayan tekniklerden kolayda örnekleme kullanılabilir (Gürbüz ve Şahin, 2018: 131). Bu nedenle araştırmada veri toplama aracı olarak anket formu hazırlanmış ve kolayda örnekleme yöntemi kullanılmıştır. Hazırlanan anket formu üç bölümden oluşturulmuştur. Anketin birinci bölümünde otel işletmelerindeki duyusal pazarlama uygulamalarını belirlemek amacıyla 26 önerme bulunmaktadır. Bu bölümdeki 26 önerme Md. Saffer Uddin'nin 2011 yılında duyusal markayı ölçmek amacıyla kullandığı ölçekten uyarlanmıştır. Ölçekte yer alan bu 26 önerme beş duyuya hitap eden dokunsal, görsel, işitsel, tatsal ve kokusal duyusal pazarlama boyutlarını içermektedir. Anketin ikinci bölümünde müşteri sadakatini ölçmek için 6 önerme bulunmaktadır. Bu 6 önerme Kahvecioğlu'nun 2018'de yapmış olduğu 
çalışmadan uyarlanmıştır. Bu iki bölümde yer alan toplam 32 önerme çoktan seçmeli 5'li Likert Ölçek (Kesinlikle Katılmıyorum, Katılmıyorum, Kararsızım, Katılıyorum ve Kesinlikle Katılıyorum) ile ölçülmeye çalışılmıştır. Son olarak hazırlanan anket formunun üçüncü bölümünde ise katılımcıların demografik özelliklerini belirlemeye yönelik 6 önerme bulunmaktadır.

\section{Evren ve Örneklemin Belirlenmesi}

Araştırmanın ana kütlesini Burdur İli ve çevresindeki turizm potansiyel değerleri yüksek olan yerleri ziyarete gelen ziyaretçiler oluşturmaktadır. Maliyet, zaman ve 2019 Aralık ayında Çin'in Wuhan kentinde ilk kez ortaya çıkan Covid-19 virüsünün Türkiye'de de görülmeye başlaması ve Covid-19 virüsünün salgın haline gelmesinden dolayı salgınla mücadele kapsamında devlet tarafından alınan önlem ve kısıtlamalar (Elibol, 2020: 178) nedeniyle Burdur İli'nin turizm potansiyeli arz eden tüm bölgelerini ziyaret eden yerli turistler ele alınamamıştır. Bu nedenle Burdur İli'ne bağlı Yeşilova ilçesinde bulunan ve günümüzde Türkiye'nin Maldivler'i olarak markalaşan ve yaz aylarında yoğun bir ziyaretçi akışına sahip olan Salda Gölü'ne ziyarete gelen yerli turistler araştırmaya dâhil edilmiştir. Salda Gölü'nü ziyarete gelen 258 yerli turiste yüz yüze anket tekniği uygulanmıştır. Çalışmada bu noktanın seçilmesinin nedeni Türkiye'nin farklı illerinden gelen ve demografik faktörleri farklı olan yerli turistlerin Salda Gölü'ne daha çok uğradıkları gözlemlenmiş ve bu değerlendirmeden hareketle Salda Gölü'ne ziyarete gelen yerli turistlerin araştırma için daha verimli olacağı düşünülmüştür.

Araştırmada iki örnekleme yönteminden yararlanılmıştır. Birinci örnekleme yöntemi alan örneklemesi yöntemidir. Bu örnekleme yönteminde Burdur İli'nin turizm potansiyeli arz eden bölgeler belirlenmiş ve zaman, maliyet ve Covid-19 salgını kısıtlamalarından dolayı Salda Gölü ele alınmıştır. Bu örnekleme yönteminde ise Salda Gölü'nde kolayda örnekleme yöntemi ile nihai örnekleme birimine ulaşmak hedeflenmiştir.

Örnek hacmi belirlenirken göz önüne bulundurulması gereken bazı önemli faktörler bulunmaktadır. Bu önemli faktörler, çalışma için alınan kararın önemi, çalışmanın özellikleri, çalışmada kullanılacak olan değişken sayısı, çalışmada kullanılacak olan analizlerin özellikleri ve kaynak sınırlamalardır (Elibol, 2020: 104). Bu nedenle bu araştırmada da en yüksek örneklem seçilmeye çalışılmıştır. Aşağıda belirtilen formülden yararlanılarak kabul edilebilir hata \%6, evren büyüklüğü Burdur Turizm İl Müdürlüğü'nden alınan bir önceki yıla ait 2019 yılında Salda Gölü'ne gelen toplam ziyaretçi sayısı 1.795.032, güven seviyesi \%95 olarak alınmış ve sonuç olarak örneklem hacmi 258 katılımcı olarak belirlenmiştir. 
Yeterli sayıda örnek hesaplamasında aşağıdaki formülünden yararlanılmıştır.

$$
\mathrm{n}=\frac{\mathrm{N}(\mathrm{pq}) \mathrm{Z}^{2}}{(\mathrm{~N}-1) \mathrm{E}^{2}+(\mathrm{pq}) \mathrm{Z}^{2}}
$$

\section{Verilerin Analiz Yöntemi}

Araştırmada analize elverişli 258 anket formu SPSS 22.0 for Windows paket programı ile analiz edilmiştir. Bu program yardımıyla anket ölçeğinin güvenirliliğini ve geçerliliğini belirlemek için Cronbach Alpha analizinden yararlanılmıştır. Daha sonra frekans analizi, varimax rotasyonu kullanılarak açımlayıcı Faktör analizi, Korelasyon analizi, Basit ve Çoklu Regresyon analizi, T-testi ve Anavo analizlerinden yararlanılmıştır (Gürbüz ve Şahin, 2018: 259-334).

- Güvenilirlik Analizi: Anket formunda kullanılan ölçeğin güvenilirliğini belirlemek amacıyla Cronbach Alpha Testinden yararlanılmıştır.

- Frekans Analizi: Katılımcıların demografik özelliklerini belirlemek amacıyla frekans analizi ve yüzde dağıım yönteminden yararlanılmıştır.

- Faktör Analizi: Anket formunda kullanılan ölçeklerin boyutlarını belirleyebilmek amacıyla varimax rotasyonu kullanılarak açımlayıcı Faktör analizinden yararlanılmıştır. Açımlayıcı faktör analizi faktör analizi yapılan ölçeğin yapı geçerliliği hakkında bilgi veren analizdir (Ural ve Kılıç, 2005: 253).

- Korelasyon Analizi: Anket formundaki ölçekler arasındaki ilişkileri saptamak amacıyla Korelasyon analizinden yararlanılmıştır.

- Regresyon Analizi: Araştırma hipotezlerini test etmek ve bağımlı değişken ile bağımsız değişkenler arasındaki etkiyi ölçmek amacıyla Regresyon analizinden yararlanılmıştır.

- T-Testi: Araştırmada normal dağıım gösteren katılımcıların demografik özelliklerine göre farklılık olup olmadığını tespit etmek için iki değişkenli gruplarda T-testinden yararlanılmıştır.

- Anova Analizi: Araştırmada normal dağılım gösteren katılımcıların demografik özelliklerine göre farklılık olup olmadığını tespit etmek için ikiden fazla gruplarda tek yönlü varyans (Anova) analizinden yararlanılmıştır. Araştırma verilerinin normal dağılım gösterip göstermediğini tespit etmek için çarpıklık ve basıklık değerlerine bakılmıştır. 


\section{BULGULAR}

\section{Güvenilirlik Analizi Sonuçları}

Araştırmaya katılan 258 katılımcıdan elde edilen verilerin analizleri için sosyal bilimlerde kullanılan SPSS 22.0 sürümü paket programı kullanılmıştır. Anket formunun güvenilirlik analizi yapılırken Cronbach Alpha modelinden yararlanılmıştır. Anketin birinci bölümündeki dokunsal, görsel, işitsel, tatsal ve kokusal boyutlarındaki ve ikinci bölümündeki müşteri sadakati ölçeğindeki önermelere yapılan güvenilirlik analizi sonuçları aşağıdaki Tablo 2'de verilmiştir.

\begin{tabular}{|l|c|c|}
\hline \multicolumn{1}{|c|}{ Anket Boyutları } & $\begin{array}{c}\text { Cronbach's } \\
\text { Alpha }\end{array}$ & $\begin{array}{c}\text { Kriter } \\
\text { Sayısı }\end{array}$ \\
\hline Dokunsal Boyuttaki Değişkenlerin Güvenilirlik Analizi &, 887 & 6 \\
\hline Görsel Boyuttaki Değişkenlerin Güvenilirlik Analizi & .900 & 10 \\
\hline İşitsel Boyuttaki Değişkenlerin Güvenilirlik Analizi & .844 & 3 \\
\hline Tatsal Boyuttaki Değişkenlerin Güvenilirlik Analizi &, 829 & 3 \\
\hline Kokusal Boyuttaki Değişkenlerin Güvenilirlik Analizi &, 825 & 4 \\
\hline Müşteri Sadakati Ölçeği Değişkenlerin Güvenilirlik Analizi &, 959 & 6 \\
\hline Duyusal Pazarlama Ölçeğine Dair Güvenilirlik Analiz &, 850 & 26 \\
\hline Anketin Formunun Güvenilirlik Analizi &, 869 & 32 \\
\hline
\end{tabular}

Tablo 1: Anket Boyutu Güvenilirlik Analizi Sonuçları

Tablo 1' de anket boyutlarının istatistiksel güvenilirliği Cronbach Alpha yöntemi ile sınanmıştır. Cronbach's Alpha katsayısına bağlı olarak bir ölçeğin güvenilirliği $0,00<a<0,40$ ise ölçek güvenilir değil, $0,40<a<0,60$ ise ölçeğin güvenilirliği düşük, $0,60<a<0,80$ ise ölçek oldukça güvenilir ve $0,80<a<1,00$ ise ölçek yüksek derecede güvenilir şeklinde yorumlanabilir (Bayram, 2019: 194-195). Tablo 1 incelendiğinde anketin dokunsal boyuttaki önermelerin bulunduğu ölçeğin Alpha değeri 0, 887 olarak bulunmuştur. Bu değer, 0,80<a $<1,00$ arasında olduğu için bu boyutun ölçek güvenilirliğinin yüksek derecede güvenilir olduğu söylenebilir. Görsel boyuttaki önermelerin bulunduğu ölçeğin Alpha değeri 0,900 olarak bulunmuştur. Bu değer, 0,80<a $<1,00$ arasında olduğu için bu boyutun ölçek güvenilirliğinin yüksek derecede olduğu söylenebilir. İşitsel boyuttaki önermelerin bulunduğu ölçeğin Alpha değeri 0, 844 olarak bulunmuştur. Bu değer, $0,80<a<1,00$ arasında olduğu için bu boyutun ölçek güvenilirliğinin yüksek derecede olduğu söylenebilir. Tatsal boyuttaki önermelerin bulunduğu ölçeğin Alpha değeri 0, 829 olarak bulunmuştur. Bu değer, $0,80<a<1,00$ arasında olduğu için bu boyutun ölçek güvenilirliğinin yüksek derecede olduğu söylenebilir. Kokusal boyuttaki önermelerin bulunduğu ölçeğin Alpha değeri 0, 825 olarak bulunmuştur. Bu değer, $0,80<a<1,00$ arasında olduğu için bu boyutun ölçek güvenilirliğinin yüksek olduğu söylenebilir. Müşteri sadakati önermelerin bulunduğu ölçeğin Alpha değeri 0, 887 olarak bulunmuştur. Bu değer, 0,80 
$<a<1,00$ arasında olduğu için bu boyutun ölçek güvenilirliğinin yüksek derecede olduğu söylenebilir. Duyumsal pazarlama önermelerin bulunduğu ölçeğin Alpha değeri 0, 850 olarak bulunmuştur. Bu değer, 0,80 <a<1,00 arasında olduğu için bu boyutun ölçek güvenilirliğinin yüksek derecede olduğu söylenebilir. Son olarak Tablo 1 incelendiğinde anketin formu tüm önermelerin bulunduğu ölçeğin Alpha değeri 0, 850 olarak bulunmuştur. Bu değer, $0,80<a<1,00$ arasında olduğu için bu boyutun ölçek güvenilirliğinin yüksek derecede olduğu söylenebilir.

\section{Demografik Özelliklerle İlgili Sonuçlar}

Araştırmaya katılan 258 cevaplayıcının demografik özelliklerine ait verileri aşağıdaki Tablo 2'de verilmiştir.

\begin{tabular}{|l|r|r|}
\hline \multicolumn{1}{|c|}{ Cinsiyet } & Frekans & \multicolumn{1}{c|}{ Yüzde (\%) } \\
\hline Erkek & 122 & 47,3 \\
\hline Kadın & 136 & 52,7 \\
\hline Medeni Durum & Frekans & Yüzde (\%) \\
\hline Evli & 160 & 62 \\
\hline Bekâr & 98 & 38 \\
\hline Yaş Grubu & Frekans & Yüzde (\%) \\
\hline $18-29$ & 90 & 34,9 \\
\hline $30-39$ & 92 & 35,7 \\
\hline $40-49$ & 60 & 23,3 \\
\hline $50-59$ & 14 & 5,4 \\
\hline 60 ve üstü & 2 &, 8 \\
\hline Eğitim Durumu & Frekans & Yüzde (\%) \\
\hline İlköğretim-Ortaöğretim & 40 & 15,5 \\
\hline Lise & 157 & 60,9 \\
\hline Ön Lisans & 22 & 8,5 \\
\hline Lisans & 19 & 7,4 \\
\hline Lisansüstü & 20 & 7,8 \\
\hline \multicolumn{1}{|c|}{ Aylık Gelir } & Frekans & Yüzde (\%) \\
\hline 2.500 ve altı & 105 & 40,7 \\
\hline $2.501-3500$ & 102 & 39,5 \\
\hline $3.501-4500$ & 28 & 10,9 \\
\hline 4.500 ve üstü & 23 & 8,9 \\
\hline Amaç & 76 & 29,5 \\
\hline Dinlenmek & 90 & 34,9 \\
\hline Eğlenmek & 71 & 27,5 \\
\hline Yeni Yerler & 21 & 8,1 \\
\hline Görmek & 258 & 100 \\
\hline Diğer & & Yüzde (\%) \\
\hline N & Frekans & \\
\hline & &
\end{tabular}

Tablo 2: Katılımcılara Ait Sosyo-Demografik Bulgular

Yukarıdaki Tablo 2'de görüldüğü gibi araştırmaya katılan katılımcıların $\% 47,3$ 'ünü erkekler, \%52,7'sini kadınlar oluşturmaktadır. Katılımcıların medeni durumları incelendiğinde 160 katılımcının evli, 98 katılımcının ise bekâr olduğu Tablo 2'de görülmektedir. Ayrıca Tablo 2'de araştırmaya katılan katılımcıların \%15,5'i ilköğretim ve ortaöğretim, \%60,9 lise, \%8,5'i 
ön lisans, \%7,4 lisans ve \%7,8 lisansüstü mezunudur. Katılımcıların yaş grupları incelendiğinde 90 katılımcı 18-29 yaş aralığında, 92 katılımcı 30-39 yaş aralığında, 60 katılımcı 40-49 yaş aralığında, 14 katılımcı 50-59 yaş aralığında ve 2 katılımcı 60 yaş üstüdür. Katılımcıların aylık gelirleri incelendiğinde $\% 40,7$ 'si 2.500 ve altı, \%39,5'i 2.501-3.500, \%10,9'u 35014.500 ve $\% 8,9^{\prime}$ u 4.500 TL ve üstü aylık gelir düzeylerine sahiptirler. Son olarak Tablo 2 incelendiğinde 76 katılımcının amacının dinlenmek, 90 katılımcının amacının eğlenmek, 71 katılımcının yeni yerler gezip görmek ve 21 katıımcının amacının bunların dışında olduğu görülmektedir.

\begin{tabular}{|c|c|c|c|c|}
\hline \multicolumn{2}{|r|}{ Önermeler } & Ortalama & Mod & Standart \\
\hline \multirow{6}{*}{ 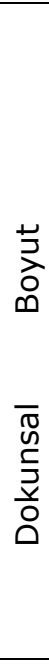 } & $\begin{array}{l}\text { Tercih edeceğim otelin havalandırma ve klima } \\
\text { sistemi mükemmel ayarlanmalı ki kendimi hiç } \\
\text { rahatsız hissetmemeliyim. }\end{array}$ & 4,78 & 5 &, 503 \\
\hline & $\begin{array}{l}\text { Tercih edeceğim otelin odasındaki yatak çok rahat } \\
\text { olmalı ki çok huzurlu ve rahat uyumalıyım. }\end{array}$ & 4,83 & 5 &, 472 \\
\hline & $\begin{array}{l}\text { Tercih edeceğim otelin odalarındaki mobilyaların } \\
\text { dokusu yumuşak olmalı ve kendimi evimde gibi } \\
\text { hissettirmelidir. }\end{array}$ & 4,79 & 5 & ,544 \\
\hline & $\begin{array}{l}\text { Tercih edeceğim otelin genel alanlarındaki } \\
\text { (restoran, bar ve lobi) mobilyaların kumaşı ve } \\
\text { dokusu oldukça konforlu olmalıdır. }\end{array}$ & 4,86 & 5 & 454, \\
\hline & $\begin{array}{l}\text { Tercih edeceğim otelin restoran ve barındaki } \\
\text { masa ve sandalyeler çok rahat olmalı ki hiç } \\
\text { kalkmak istemeyeyim. }\end{array}$ & 4,64 & 5 & 648 \\
\hline & $\begin{array}{l}\text { Tercih edeceğim otelin havlu, sabun, şampuan ve } \\
\text { terlik gibi kişisel ürünleri hem şık hem de kullanışı } \\
\text { olmalı ki kendimi özel hissetmeliyim. }\end{array}$ & 4,74 & 5 & ,541 \\
\hline \multirow{11}{*}{ 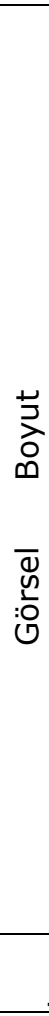 } & $\begin{array}{l}\text { Tercih edeceğim otelin restoran ve barları çok şık } \\
\text { dekore edilmelidir. }\end{array}$ & 4,71 & 5 &, 555 \\
\hline & $\begin{array}{l}\text { Tercih edeceğim otelin aydınlatması etkileyici ve } \\
\text { görkemli olmalıdır. }\end{array}$ & 4,59 & 5 & ,661 \\
\hline & $\begin{array}{l}\text { Tercih edeceğim otel odalarının dizaynı } \\
\text { beklediğim standartların üstünde olmalıdır. }\end{array}$ & 4,63 & 5 & ,631 \\
\hline & $\begin{array}{l}\text { Tercih edeceğim otelin lobisi beni cezbedecek } \\
\text { şekilde dizayn edilmelidir. }\end{array}$ & 4,64 & 5 & ,648 \\
\hline & $\begin{array}{l}\text { Tercih edeceğim otelin yiyecek ve içeceklerinin } \\
\text { sunumu görsel olarak harika olmalıdır. }\end{array}$ & 4,59 & 5 & ,631 \\
\hline & $\begin{array}{l}\text { Tercih edeceğim otelin bar kısmı çok şık dekore } \\
\text { edilmiş olmalıdır. }\end{array}$ & 4,64 & 5 & ,610 \\
\hline & $\begin{array}{l}\text { Tercih edeceğim otelin bahçe peyzajı harika } \\
\text { olmalıdır. }\end{array}$ & 4,63 & 5 & ,606 \\
\hline & $\begin{array}{l}\text { Tercih edeceğim otelin restoranı çok şık dekore } \\
\text { edilmiş olmalıdır. }\end{array}$ & 4,64 & 5 &, 578 \\
\hline & $\begin{array}{l}\text { Tercih edeceğim otelin dış mimarisi daha önce } \\
\text { kaldığım ve gördüğüm otellerden daha sıra dışı } \\
\text { olmalıdır. }\end{array}$ & 4,63 & 5 & ,625 \\
\hline & $\begin{array}{l}\text { Tercih edeceğim otelin internet sitesi görsel } \\
\text { olarak beni cezbederse o oteli tercih etmemde çok } \\
\text { etkili olur. }\end{array}$ & 4,60 & 5 & ,659 \\
\hline & $\begin{array}{l}\text { Tercih edeceğim otelde çalan müzikler beni } \\
\text { tamamen tatilde hissettirmelidir. }\end{array}$ & 4,53 & 5 & ,744 \\
\hline
\end{tabular}




\section{Ali Elibol}

\begin{tabular}{|c|c|c|c|c|}
\hline & $\begin{array}{l}\text { Tercih edeceğim otelin DJ performansı harika ve } \\
\text { müzikleri çok hoşuma gidecek şekilde olmalıdır. }\end{array}$ & 4,55 & 5 & ,705 \\
\hline & $\begin{array}{l}\text { Tercih edeceğim otelin kendisine has fon müziğini } \\
\text { nerde duysam bana tercih ettiğim oteli } \\
\text { hatırlatmalıdır. }\end{array}$ & 4,52 & 5 & ,728 \\
\hline \multirow{3}{*}{ 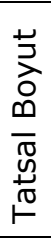 } & $\begin{array}{l}\text { Tercih edeceğim otelin yiyeceklerinin tatları } \\
\text { damağıma göre olmalıdır. }\end{array}$ & 4,58 & 5 & ,657 \\
\hline & $\begin{array}{l}\text { Tercih edeceğim otelin spesiyal kokteylinin tadı } \\
\text { damağımda kalmalıdır. }\end{array}$ & 4,59 & 5 & ,599 \\
\hline & $\begin{array}{l}\text { Tercih edeceğim otelin yiyecek ve içeceklerinin } \\
\text { sunumu iştah açıcı olmalıdır. }\end{array}$ & 4,67 & 5 & ,541 \\
\hline \multirow{4}{*}{ 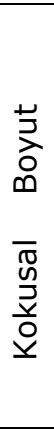 } & $\begin{array}{l}\text { Tercih edeceğim otelin özel olarak kendine has } \\
\text { kokusunu başka bir yerde duyumsadığım zaman } \\
\text { bana o oteli hatırlatmalıdır. }\end{array}$ & 4,74 & 5 & ,562 \\
\hline & $\begin{array}{l}\text { Tercih edeceğim otelin restoranındaki ve } \\
\text { barındaki koku iştah açıcı olmalıdır. }\end{array}$ & 4,74 & 5 & ,582 \\
\hline & $\begin{array}{l}\text { Tercih edeceğim otelin lobisindeki koku beni daha } \\
\text { en baştan cezbetmeli ve o oteli tercih ettiğim için } \\
\text { beni mutlu hissettirmelidir. }\end{array}$ & 4,79 & 5 & ,492 \\
\hline & $\begin{array}{l}\text { Tercih edeceğim otelin odalarındaki ve } \\
\text { koridorlarındaki koku beni huzurlu bir ortamda } \\
\text { olduğumu hissettirmelidir. }\end{array}$ & 4,76 & 5 & ,519 \\
\hline \multirow{6}{*}{ 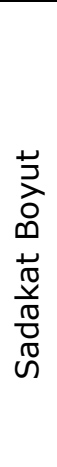 } & $\begin{array}{l}\text { Bu özelliklere sahip bir oteli kesinlikle çevremdeki } \\
\text { ve diğer kişilere tavsiye ederim. }\end{array}$ & 4,52 & 5 & ,586 \\
\hline & $\begin{array}{l}\text { Çevremdeki ve diğer kişileri bu özeliklere sahip bir } \\
\text { oteli ziyaret etmeleri için teşvik ederim. }\end{array}$ & 4,51 & 5 & ,656 \\
\hline & $\begin{array}{l}\text { Bu özelliklere sahip bir otelde tekrar konaklamayı } \\
\text { düşünürüm. }\end{array}$ & 4,47 & 5 & ,723 \\
\hline & $\begin{array}{l}\text { Diğer otellerin fiyatları daha cazip olsa da bu } \\
\text { özelliklere sahip bir oteli tercih ederim. }\end{array}$ & 4,39 & 5 & ,802 \\
\hline & $\begin{array}{l}\text { Bu özelliklere sahip bir otelle ilgili olumlu } \\
\text { düşüncelerimi başkalarına anlatırım. }\end{array}$ & 4,49 & 5 & ,713 \\
\hline & $\begin{array}{l}\text { Bu özelliklere sahip bir otelle ilgili olumlu } \\
\text { düşüncelerimi sosyal medyada paylaşırım. }\end{array}$ & 4,47 & 5 & 690 \\
\hline
\end{tabular}

Tablo 3. Ölçek Boyutlarının Ortalama-Mod ve Standart Sapma Değerleri

\section{Faktör Analizi ve Anket Boyutları}

Araştırmada Korelasyon analizi, Regresyon analizi, T-testi ve Anova analizleri yapılmadan önce araştırmalarda çok sayıda madde üzerinden madde sayısından daha az sayıda alt boyutlar ile çalışma olanağı tanıyan (Gürbüz ve Şahin, 2018: 318) ve faktör analizi yapılan ölçeğin yapı geçerliliği hakkında bilgi veren (Ural ve Kılıç, 2005: 253) açımlayıcı faktör analizi, duyusal pazarlama ölçeğinde yer alan 26 önermenin indirgenmesi ve bu önermeleri ortak bir anlam taşıyan boyutlar altında toplayabilmek amacıyla uygulanmıştır. Açımlayıcı faktör analizinin yapılabilmesi için katılımc sayısının yeterli olup olmadığını saptamak için Kaiser-Mayer-Olkin (KMO) değerine bakılmış ve bu değer 0,70 değerinin üzerinde 0,871 olarak bulunduğu için araştırma için iyi bir değer olarak kabul edilmiştir. Duyusal pazarlama uygulamaları boyutları için uygulanan açımlayıcı faktör analizi sonuçları aşağıdaki Tablo 4'de gösterilmiştir. 


\section{Ali Elibol}

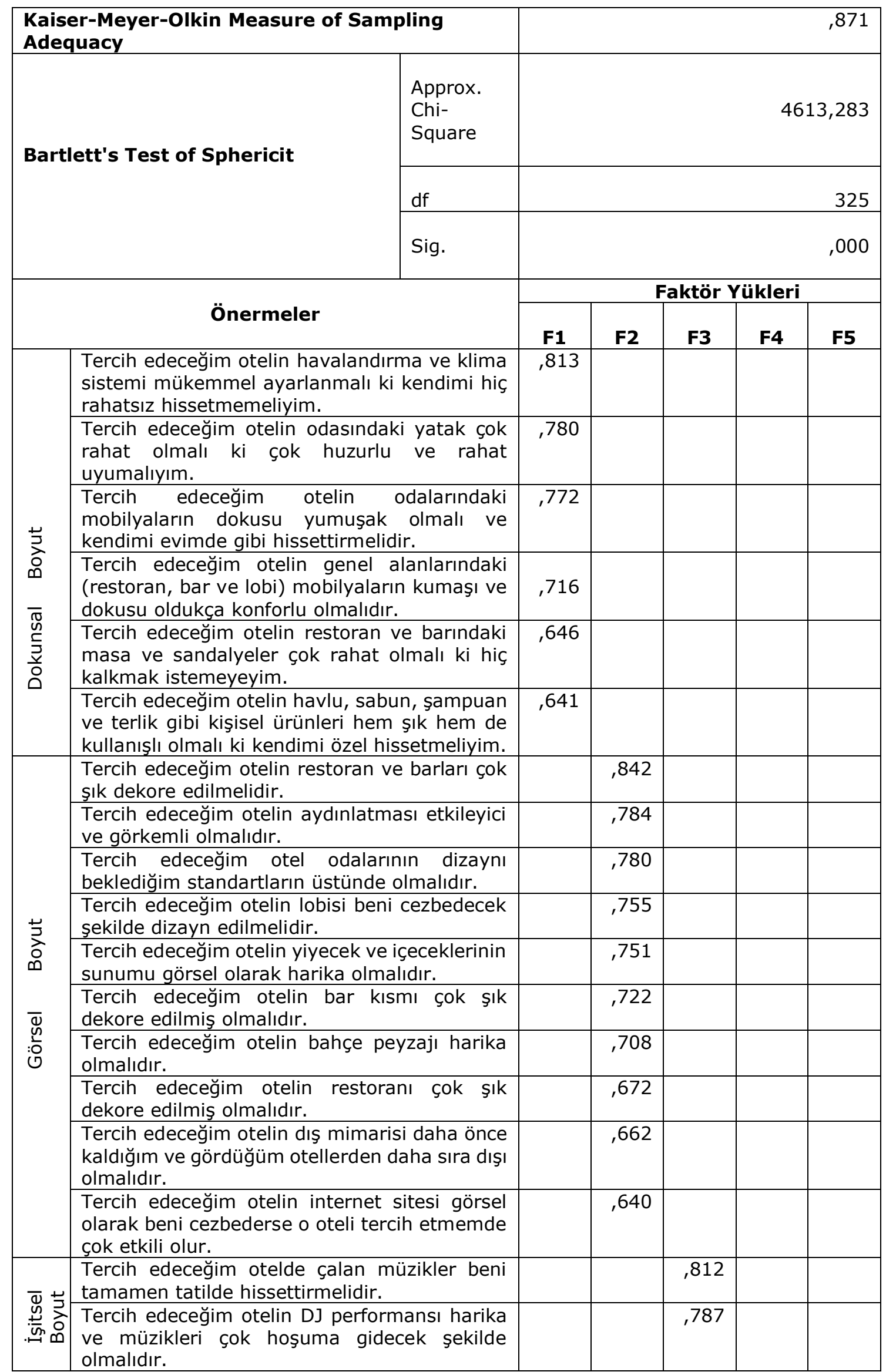




\section{Ali Elibol}

\begin{tabular}{|c|c|c|c|c|}
\hline & $\begin{array}{l}\text { Tercih edeceğim otelin kendisine has fon } \\
\text { müziğini nerde duysam bana tercih ettiğim } \\
\text { oteli hatırlatmalıdır. }\end{array}$ & ,733 & & \\
\hline \multirow{3}{*}{ 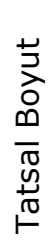 } & $\begin{array}{l}\text { Tercih edeceğim otelin yiyeceklerinin tatları } \\
\text { damağıma göre olmalıdır. }\end{array}$ & & 797 & \\
\hline & $\begin{array}{l}\text { Tercih edeceğim otelin spesiyal kokteylinin } \\
\text { tadı damağımda kalmalıdır. }\end{array}$ & & ,723 & \\
\hline & $\begin{array}{l}\text { Tercih edeceğim otelin yiyecek ve içeceklerinin } \\
\text { sunumu iştah açıcı olmalıdır. }\end{array}$ & & 666 & \\
\hline \multirow{4}{*}{ 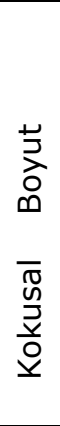 } & $\begin{array}{l}\text { Tercih edeceğim otelin özel olarak kendine has } \\
\text { kokusunu başka bir yerde duyumsadığım } \\
\text { zaman bana o oteli hatırlatmalıdır. }\end{array}$ & & & 907 \\
\hline & $\begin{array}{l}\text { Tercih edeceğim otelin restoranındaki ve } \\
\text { barındaki koku iştah açıcı olmalıdır. }\end{array}$ & & & 867 \\
\hline & $\begin{array}{l}\text { Tercih edeceğim otelin lobisindeki koku beni } \\
\text { daha en baştan cezbetmeli ve o oteli tercih } \\
\text { ettiğim için beni mutlu hissettirmelidir. }\end{array}$ & & & 825 \\
\hline & $\begin{array}{l}\text { Tercih edeceğim otelin odalarındaki ve } \\
\text { koridorlarındaki koku beni huzurlu bir ortamda } \\
\text { olduğumu hissettirmelidir. }\end{array}$ & & & 697 \\
\hline
\end{tabular}

Tablo 4: Varimax Rotasyona Tabi Tutulmuş 26 Önermenin Faktör Matrisi Sonuçları

Faktör analizi sonuçlarına göre, 26 maddelik ölçeğin tek boyutluluk özelliği taşımadığı Tablo 4'de görülmektedir. Bu nedenle Tablo 4'deki faktör analizi sonuçlarına göre maddelerden 6 önermenin dokunsal boyutu, 10 önermenin görsellik boyutu, 3 önermenin işitsel boyutu, 3 önermenin tatsal boyutu ve son 4 önermenin kokusal boyutu ölçtüğü görülmüş ve ölçek beş boyut altında toplanmıştır.

\begin{tabular}{|c|c|c|c|}
\hline \multicolumn{3}{|c|}{ Kaiser-Meyer-Olkin Measure of Sampling Adequacy. } & \\
\hline \multirow{3}{*}{\multicolumn{2}{|c|}{ Bartlett's Test of Sphericity }} & $\begin{array}{l}\text { Approx. Chi- } \\
\text { Square }\end{array}$ & 1760,697 \\
\hline & & df & 15 \\
\hline & & Sig. &, 000 \\
\hline \multicolumn{3}{|c|}{ Önermeler } & Faktör Yükleri \\
\hline \multirow{6}{*}{ 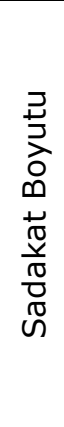 } & \multicolumn{2}{|c|}{$\begin{array}{l}\text { Bu özelliklere sahip bir oteli kesinlikle çevremdeki ve diğer kişilere } \\
\text { tavsiye ederim. }\end{array}$} & 930 \\
\hline & \multicolumn{2}{|c|}{$\begin{array}{l}\text { Çevremdeki ve diğer kişileri bu özeliklere sahip bir oteli ziyaret } \\
\text { etmeleri için teşvik ederim. }\end{array}$} & ,901 \\
\hline & \multicolumn{2}{|c|}{ Bu özelliklere sahip bir otelde tekrar konaklamayı düşünürüm. } & ,923 \\
\hline & \multicolumn{2}{|c|}{$\begin{array}{l}\text { Diğer otellerin fiyatları daha cazip olsa da bu özelliklere sahip bir } \\
\text { oteli tercih ederim. }\end{array}$} & ,921 \\
\hline & \multicolumn{2}{|c|}{$\begin{array}{l}\text { Bu özelliklere sahip bir otelle ilgili olumlu düşüncelerimi başkalarına } \\
\text { anlatırım. }\end{array}$} & 901 \\
\hline & \multicolumn{2}{|c|}{$\begin{array}{l}\text { Bu özelliklere sahip bir otelle ilgili olumlu düşüncelerimi sosyal } \\
\text { medyada paylaşırım. }\end{array}$} & 897 \\
\hline
\end{tabular}

Tablo 5: Müşteri Sadakati Ölçeğine İlişkin Faktör Analizi Sonuçları

Müşteri sadakatine ilişkin faktör analizi sonuçları ise Tablo 5'de verilmiştir. Yapılan faktör analizi sonucunda müşteri sadakati ölçeğini Kaiser-Mayer-Olkin (KMO) değeri ,912, Bartlett's Küresellik değeri (df.) 15, Bartlett's Küresellik önem seviyesi değeri (sig.) ,000 olarak saptanmıştır. 


\section{Ali Elibol}

Bulunan bu analiz sonuçlarına göre ölçeğin faktör analizi için uygun olduğunu göstermektedir. Müşteri sadakati ölçeğinde yer alan 6 tane önerme tek faktör altında toplanmış ve faktör yükleri yukarıdaki Tablo 5'de gösterilmiştir.

\section{Normal Dağılım Testlerine İlişkin Bulgular}

Araştırma verilerinin normal dağılım gösterip göstermediklerini anlayabilmek için çarpıklık (skewness) ve basıklık (kurtosis) değerlerine bakılmıştır. Tablo 6'da duyusal pazarlama ölçeğine ve müşteri sadakati ölçeğine ilişkin normal dağılım gösteren çarpıklık ve basıklık değerleri gösterilmiştir.

\begin{tabular}{|c|c|c|c|c|c|}
\hline \multicolumn{2}{|r|}{ Önermeler } & Çarpıklık & Std. & Basıklık & Std. \\
\hline \multirow{6}{*}{ 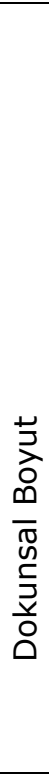 } & $\begin{array}{l}\text { Tercih edeceğim otelin havalandırma ve } \\
\text { klima sistemi mükemmel ayarlanmalı ki } \\
\text { kendimi hiç rahatsız hissetmemeliyim. }\end{array}$ & 1,009 & , 152 & 1,272 & ,302 \\
\hline & $\begin{array}{l}\text { Tercih edeceğim otelin odasındaki yatak } \\
\text { çok rahat olmalı ki çok huzurlu ve rahat } \\
\text { uyumalıyım. }\end{array}$ & 1,573 & , 152 & 1,472 & ,302 \\
\hline & $\begin{array}{l}\text { Tercih edeceğim otelin odalarındaki } \\
\text { mobilyaların dokusu yumuşak olmalı ve } \\
\text { kendimi evimde gibi hissettirmelidir. }\end{array}$ & 790 & ,152 & 1,544 & ,302 \\
\hline & $\begin{array}{l}\text { Tercih edeceğim otelin genel alanlarındaki } \\
\text { (restoran, bar ve lobi) mobilyaların } \\
\text { kumaşı ve dokusu oldukça konforlu } \\
\text { olmalıdır. }\end{array}$ & 873 & 152 & ,954 & ,302 \\
\hline & $\begin{array}{l}\text { Tercih edeceğim otelin restoran ve } \\
\text { barındaki masa ve sandalyeler çok rahat } \\
\text { olmalı ki hiç kalkmak istemeyeyim. }\end{array}$ & 1,682 & 152 & 668 & ,302 \\
\hline & $\begin{array}{l}\text { Tercih edeceğim otelin havlu, sabun, } \\
\text { şampuan ve terlik gibi kişisel ürünleri } \\
\text { hem şık hem de kullanışlı olmalı ki } \\
\text { kendimi özel hissetmeliyim. }\end{array}$ & 1,826 & 152 & 1,571 & ,302 \\
\hline \multirow{9}{*}{ 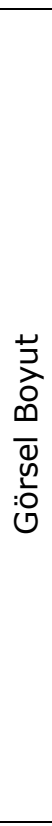 } & $\begin{array}{l}\text { Tercih edeceğim otelin restoran ve barları } \\
\text { çok şık dekore edilmelidir. }\end{array}$ & ,715 & , 152 & ,535 & ,302 \\
\hline & $\begin{array}{l}\text { Tercih edeceğim otelin aydınlatması } \\
\text { etkileyici ve görkemli olmalıdır. }\end{array}$ & ,590 & ,152 & 961 & ,302 \\
\hline & $\begin{array}{l}\text { Tercih edeceğim otel odalarının dizaynı } \\
\text { beklediğim standartların üstünde } \\
\text { olmalıdır. }\end{array}$ & ,986 & ,152 &,- 631 & ,302 \\
\hline & $\begin{array}{l}\text { Tercih edeceğim otelin lobisi beni } \\
\text { cezbedecek şekilde dizayn edilmelidir. }\end{array}$ & 1,640 & , 152 & ,638 & ,302 \\
\hline & $\begin{array}{l}\text { Tercih edeceğim otelin yiyecek ve } \\
\text { içeceklerinin sunumu görsel olarak harika } \\
\text { olmalıdır. }\end{array}$ & 1,826 & , 152 & 1,631 & ,302 \\
\hline & $\begin{array}{l}\text { Tercih edeceğim otelin bar kısmı çok şık } \\
\text { dekore edilmiş olmalıdır. }\end{array}$ & ,640 & 152 & 810 & ,302 \\
\hline & $\begin{array}{l}\text { Tercih edeceğim otelin bahçe peyzajı } \\
\text { harika olmalıdır. }\end{array}$ & 836 & , 152 & ,606 & ,302 \\
\hline & $\begin{array}{l}\text { Tercih edeceğim otelin restoranı çok şık } \\
\text { dekore edilmiş olmalıdır. }\end{array}$ & ,613 & ,152 &,- 578 & ,302 \\
\hline & $\begin{array}{l}\text { Tercih edeceğim otelin dıs mimarisi daha } \\
\text { önce kaldığım ve gördüğüm otellerden } \\
\text { daha sıra dışı olmalıdır. }\end{array}$ & 621 & ,152 &,- 254 & ,302 \\
\hline
\end{tabular}




\section{Ali Elibol}

\begin{tabular}{|c|c|c|c|c|c|}
\hline & $\begin{array}{l}\text { Tercih edeceğim otelin internet sitesi } \\
\text { görsel olarak beni cezbederse o oteli } \\
\text { tercih etmemde çok etkili olur. }\end{array}$ & ,506 & 152 & ,654 & ,302 \\
\hline \multirow{3}{*}{ 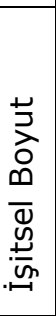 } & $\begin{array}{l}\text { Tercih edeceğim otelde çalan müzikler } \\
\text { beni tamamen tatilde hissettirmelidir. }\end{array}$ & ,536 & 152 & ,704 & ,302 \\
\hline & $\begin{array}{l}\text { Tercih edeceğim otelin DJ performansı } \\
\text { harika ve müzikleri çok hoşuma gidecek } \\
\text { sekilde olmalıdır. }\end{array}$ & 665 & 152 & ,905 & 302 \\
\hline & $\begin{array}{l}\text { Tercih edeceğim otelin kendisine has fon } \\
\text { müziğini nerde duysam bana tercih } \\
\text { ettiğim oteli hatırlatmalıdır. }\end{array}$ & 1,522 & 152, & 788 & ,302 \\
\hline \multirow{3}{*}{ 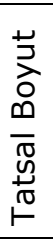 } & $\begin{array}{l}\text { Tercih edeceğim otelin yiyeceklerinin } \\
\text { tatları damağıma göre olmalıdır. }\end{array}$ & ,582 & ,152 &,- 657 & ,302 \\
\hline & $\begin{array}{l}\text { Tercih edeceğim otelin spesiyal } \\
\text { kokteylinin tadı damağımda kalmalıdır. }\end{array}$ & ,596 & 152 &,- 549 & ,302 \\
\hline & $\begin{array}{l}\text { Tercih edeceğim otelin yiyecek ve } \\
\text { içeceklerinin sunumu iştah açıcı olmalıdır. }\end{array}$ & ,678 & 152 & 641 & ,302 \\
\hline \multirow{4}{*}{ 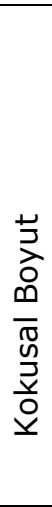 } & $\begin{array}{l}\text { Tercih edeceğim otelin özel olarak } \\
\text { kendine has kokusunu başka bir yerde } \\
\text { duyumsadığım zaman bana o oteli } \\
\text { hatırlatmalıdır. }\end{array}$ & ,748 & , 152 & ,362 & ,302 \\
\hline & $\begin{array}{l}\text { Tercih edeceğim otelin restoranındaki ve } \\
\text { barındaki koku iştah açıcı olmalıdır. }\end{array}$ & ,740 & ,152 & 482 & ,302 \\
\hline & $\begin{array}{l}\text { Tercih edeceğim otelin lobisindeki koku } \\
\text { beni daha en baştan cezbetmeli ve o oteli } \\
\text { tercih ettiğim için beni mutlu } \\
\text { hissettirmelidir. }\end{array}$ & ,792 & ,152 & 792 & ,302 \\
\hline & $\begin{array}{l}\text { Tercih edeceğim otelin odalarındaki ve } \\
\text { koridorlarındaki koku beni huzurlu bir } \\
\text { ortamda olduğumu hissettirmelidir. }\end{array}$ & 1,760 & ,152 & 619 & ,302 \\
\hline \multirow{6}{*}{ 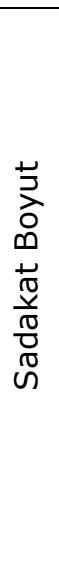 } & $\begin{array}{l}\text { Bu özelliklere sahip bir oteli kesinlikle } \\
\text { çevremdeki ve diğer kişilere tavsiye } \\
\text { ederim. }\end{array}$ & 1,524 & 152 & 1,586 & ,302 \\
\hline & $\begin{array}{l}\text { Çevremdeki ve diğer kişileri bu özeliklere } \\
\text { sahip bir oteli ziyaret etmeleri için teşvik } \\
\text { ederim. }\end{array}$ & 1,510 & 152 & 1,856 & ,302 \\
\hline & $\begin{array}{l}\text { Bu özelliklere sahip bir otelde tekrar } \\
\text { konaklamayı düşünürüm. }\end{array}$ & 1,470 & 152 & 1,230 & 302 \\
\hline & $\begin{array}{l}\text { Diğer otellerin fiyatları daha cazip olsa da } \\
\text { bu özelliklere sahip bir oteli tercih ederim. }\end{array}$ & 1,398 & 152 & 1,802 & ,302 \\
\hline & $\begin{array}{l}\text { Bu özelliklere sahip bir otelle ilgili olumlu } \\
\text { düşüncelerimi başkalarına anlatırım. }\end{array}$ & 892 & ,152 & ,758 & ,302 \\
\hline & $\begin{array}{l}\text { Bu özelliklere sahip bir otelle ilgili olumlu } \\
\begin{array}{l}\text { düşüncelerimi } \\
\text { paylaşırım. }\end{array}\end{array}$ & ,780 & 152 & 690 & ,302 \\
\hline
\end{tabular}

Tablo 6: Dokunsal-Görsel-İşitsel-Tatsal-Kokusal ve Sadakat Örmelerine Dair Normallik Test Sonuçları

Tablo 6'da çarpıklık ve basıklık değerleri incelendiğinde verilerin -2 ile +2 arasında değerler aldığı görülmektedir. Gegez'e (2010) göre, normal dağılımın sağlanması için çarpıklık ve basıklık değerlerinin -3 ile +3 aralığında olması, Gürbüz ve Şahin'e (2018) göre ise -2 ile +2 aralığında olması gerekmektedir. Bu nedenle Tablo 6'da çarpıklık ve basıklık değerleri incelendiğinde dağılımın normal dağılım sergilediği görüldüğü için gruplar arası yapılan analizlerde parametrik testler uygulanmıştır. 


\section{Ali Elibol}

\section{Araştırma Hipotezlerinin Sonuçları}

Araştırmada faktör analizi sonucunda elde edilen bağımsız değişken dokunsal, görsel, işitsel, tatsal ve kokusal boyutlar ile bağımlı değişken müşteri sadakati arasındaki ilişkiyi belirlemek için korelasyon analizi yapılmıştır. Tablo 7'de korelasyon analizi sonuçları verilmiştir.

\begin{tabular}{|c|c|c|c|c|c|c|c|}
\hline & & $\begin{array}{c}\text { Dokunsal } \\
\text { Boyut }\end{array}$ & $\begin{array}{l}\text { Görsel } \\
\text { Boyut }\end{array}$ & $\begin{array}{l}\text { İssitsel } \\
\text { Boyut }\end{array}$ & $\begin{array}{l}\text { Tatsal } \\
\text { Boyut }\end{array}$ & $\begin{array}{c}\text { Kokusal } \\
\text { Boyut }\end{array}$ & $\begin{array}{c}\text { Müşteri } \\
\text { Sadakati }\end{array}$ \\
\hline \multirow[b]{2}{*}{$\begin{array}{l}\text { Dokunsal } \\
\text { Boyut }\end{array}$} & $\begin{array}{l}\text { Spearman } \\
\text { Correlation }\end{array}$ & & & & & & \\
\hline & $\begin{array}{l}\text { Sig. } \\
\text { Tailed }) \\
\mathrm{N}\end{array}$ & $\begin{array}{r}- \\
400 \\
\end{array}$ & & & & & \\
\hline \multirow{3}{*}{$\begin{array}{l}\text { Görsel } \\
\text { Boyut }\end{array}$} & $\begin{array}{l}\text { Spearman } \\
\text { Correlation }\end{array}$ &, $640 * *$ & 1,000 & & & & \\
\hline & Sig. $\quad$ (2- & ,000 & - & & & & \\
\hline & $\begin{array}{l}\text { Tailed) } \\
\mathrm{N}\end{array}$ & & 258 & & & & \\
\hline \multirow{3}{*}{$\begin{array}{l}\text { İşitsel } \\
\text { Boyut }\end{array}$} & $\begin{array}{l}\text { Spearman } \\
\text { Correlation }\end{array}$ & $481 * *$ & ,568** & 1,000 & & & \\
\hline & Sig. (2- & ,000 & ,000 & - & & & \\
\hline & & 258 & 258 & 258 & & & \\
\hline \multirow{4}{*}{$\begin{array}{l}\text { Tatsal } \\
\text { Boyut }\end{array}$} & $\begin{array}{l}\text { Spearman } \\
\text { Correlation }\end{array}$ & $408 * *$ & ,609** & ,763** & 1,000 & & \\
\hline & & مח & & & & & \\
\hline & $\begin{array}{l}\text { Sig. } \\
\text { Tailed) }\end{array}$ & ,000 & ,000 & 000 & - & & \\
\hline & $\mathrm{N}$ & 258 & 258 & 258 & 258 & & \\
\hline \multirow{3}{*}{$\begin{array}{l}\text { Kokusal } \\
\text { Boyut }\end{array}$} & $\begin{array}{l}\text { Spearman } \\
\text { Correlation }\end{array}$ & $140 *$ & ,193** & 158* & ,153* & 1,000 & \\
\hline & Sig. (2- & 0,76 & 078 & ,422 & ,513 & - & \\
\hline & $N$ & 258 & 258 & 258 & 258 & 258 & \\
\hline \multirow{3}{*}{$\begin{array}{l}\text { Müşteri } \\
\text { Sadakati }\end{array}$} & $\begin{array}{l}\text { Spearman } \\
\text { Correlation }\end{array}$ & 197** & ,193** & ,223** & $316 * *$ & 195** & 1,000 \\
\hline & $\begin{array}{l}\text { Sig. } \\
\text { Tailed) }\end{array}$ & ,001 & ,002 & ,000 & ,000 & ,002 & \\
\hline & $\mathrm{N}$ & 258 & 258 & 258 & 258 & 258 & 258 \\
\hline
\end{tabular}

Tablo 7: Otel İşletmelerinde Duyusal Pazarlama Uygulamalarının Müşteri Sadakatine İlişkin Korelasyon Analizi Sonuçları

Tablo 7'de önermeler arasında ilişkinin olup olmadığını belirlemek amacıyla yapılan Spearman Korelasyon analizi sonuçlarına göre otel işletmelerinde duyusal pazarlama uygulamalarına ilişkin alt boyutlar olan dokunsal boyut, görsel boyut, işitsel boyut, tatsal ve kokusal boyut ile müşteri sadakati önermeleri arasında pozitif yönlü ilişkinin olduğu ve bu ilişkilerin $p=0,002$ düzeyinde anlamlı ilişkiler olduğu sonucuna ulaşılmıştır. 


\section{Ali Elibol}

- $\mathrm{H}_{1}$ Otel işletmelerinde duyusal pazarlama uygulamalarının müşteri sadakati üzerinde anlamlı bir etkiye sahiptir.

- $\mathrm{H}_{2}$ Konaklama işletmelerinde dokunsal boyutun müşteri sadakati üzerinde anlamlı bir etkiye sahiptir.

- $\mathrm{H}_{3}$ Konaklama işletmelerinde görsellik boyutun müşteri sadakati üzerinde anlamlı bir etkiye sahiptir.

- $\mathrm{H}_{4}$ Konaklama işletmelerinde işitsel boyutun müşteri sadakati üzerinde anlamlı bir etkiye sahiptir.

- $\mathrm{H}_{5}$ Konaklama işletmelerinde tatsal boyutun müşteri sadakati üzerinde anlamlı bir etkiye sahiptir.

- $\mathrm{H}_{6}$ Konaklama işletmelerinde kokusal boyutun müşteri sadakati üzerinde anlamlı bir etkiye sahiptir.

\begin{tabular}{|c|c|c|c|}
\hline & Beta & $\mathbf{t}$ & Sig. (p) \\
\hline Sabit & & $-4,806$ & 000 \\
\hline Duyusal Pazarlama Uygulamaları & 816,532 & &, 000 \\
\hline $\mathrm{R}$ & & & 826 \\
\hline R Square & & & 665 \\
\hline Düzeltilmiş $\mathrm{R}^{2}$ & & & ,658 \\
\hline $\mathrm{F}$ & & & 641,174 \\
\hline $\mathrm{p}$ & & & ,000 \\
\hline Durbin-Watson & & & 1,452 \\
\hline $\begin{array}{l}\text { Duyusal Pazarlama } \\
\text { Uygulamaları Boyutları }\end{array}$ & Beta & $\mathbf{t}$ & Sig. (p) \\
\hline Sabit & & $-4,351$ & , 000 \\
\hline Dokunsal Boyut & ,393 & 8,700 & ,000 \\
\hline Görsel Boyut & 321 & 7,106 & 000 \\
\hline İşitsel Boyut &, 182 & 4,029 & ,002 \\
\hline Tatsal Boyut &, 444 & 9,829 & ,000 \\
\hline Kokusal Boyut & 101 & 2,236 & 005 \\
\hline $\mathrm{R}$ & & & 835 \\
\hline R Square & & & ,691 \\
\hline Düzeltilmiş $\mathrm{R}^{2}$ & & & ,688 \\
\hline$F$ & & & 261,359 \\
\hline$p$ & & &, 000 \\
\hline Durbin-Watson & & & 1,604 \\
\hline
\end{tabular}

Tablo 8: Otel İşletmelerinde Duyusal Pazarlama Uygulamalarının Müşteri Sadakatine İlişkin Basit Doğrusal ve Çoklu Doğrusal Regresyon Analizi Sonuçları

Tablo 8'de otel işletmelerinde duyusal pazarlama uygulamaları ile müşteri sadakati arasındaki ilişkiyi açıklayabilmek için basit doğrusal regresyon analizi sonuçları verilmiştir. Bu sonuçlar doğrultusunda $\mathrm{R}=, 826$ bulunmuştur. Bu değere göre müşteri sadakati ile duyusal pazarlama uygulamaları arasında korelasyon değeri olup pozitif yönde anlamlı bir ilişki 


\section{Ali Elibol}

olduğu sonucuna ulaşılmıştır. Düzeltilmiş $\mathrm{R}^{2}$ analiz sonucunda ,658 bulunmuş ve bu değer duyusal pazarlama uygulamalarının müşteri sadakatini \%65,8 oranında açıkladığı görülmektedir. Ayrıca Tablo 8 incelendiğinde Durbin-Watson katsayısı 1,452 olduğundan dolayı kurulan modelde oto korelasyon sorunu olmadığı ve $F: 641,174$ ile $p=, 000$ olduğu için modelin istatiksel olarak anlamlı olduğu sonucuna da ulaşılmıştır. Bu analiz sonuçları doğrultusunda $\mathrm{H}_{1}$ hipotezi kabul edilmiştir.

Konaklama işletmelerinde dokunsal, görsel, işitsel, tatsal ve kokusal duyusal pazarlama alt boyutlarının müşteri sadakati arasındaki etki ve ilişki düzeylerini incelemek için verilere çoklu doğrusal regresyon analizi uygulanmış ve bu analize ilişkin bulgulara Tablo 8'de yer verilmiştir. Elde edilen Tablo 8'deki sonuçlara göre, duyusal pazarlama uygulamaları ile müşteri sadakati değişkenleri arasında ,835 oranında bir korelasyon bulunmaktadır. Daha sonra Tablo 8 'den anlaşıldığı üzere müşteri sadakatinin (Düzeltilmiş $R^{2}$ ) \%68'i duyusal pazarlama boyutları ile açıklanabilmekte ve Durbin - Watson katsayısının 1,604 olması kurulan modelde oto korelasyon sorunun olmadığını göstermektedir. Ayrıca analiz sonucunda $F$ değeri 261,359 ve $p$ değeri ,000 olduğu için regresyon modelinin bir bütün olarak her boyutunda istatistiksel olarak anlamlı olduğu görülmektedir.

Tablo 8'de verilen bulgulara göre ayrı ayrı boyutlar açısından incelendiğinde dokunsal boyutun müşteri sadakati üzerinde anlamlı ve pozitif yönde bir ilişkiye sahip olduğu görülmektedir $(\beta=, 393$ ve $p=, 000)$. $\mathrm{Bu}$ sonuçlar doğrultusunda $\mathrm{H}_{2}$ hipotezi kabul edilmiştir. Daha sonra Tablo 8 'de görsel boyutun müşteri sadakati üzerindeki etkisini incelemek için $\beta$ ve $p$ değerlerine baktığımızda $\beta=, 321$ ve $p=, 000$ olduğundan dolayı görsel boyutun müşteri sadakati üzerinde anlamlı ve pozitif yönde bir ilişkiye sahip olduğu görülmektedir. Bu sonuçlar doğrultusunda $\mathrm{H}_{3}$ hipotezi kabul edilmiştir. Tablo 8 tekrar incelendiğinde işitsel $(\beta=, 182$ ve $p=, 002)$ tatsal $(\beta=, 444$ ve $p=, 000)$ ve kokusal $(\beta=, 101$ ve $p=, 005)$ boyutların müşteri sadakati üzerinde anlamlı ve pozitif yönde ilişkiye sahip olduğu da görülmektedir. Bu analiz sonuçları doğrultusunda $\mathrm{H}_{4}, \mathrm{H}_{5}$ ve $\mathrm{H}_{6}$ hipotezleri de kabul edilmiştir.

Araştırmada katıımcıların duyusal pazarlama uygulamalarına yönelik ilişkin değerlendirmelerin demografik faktörlere göre anlamlı bir farlılığın olup olmadığı incelenmiştir. Katılımcıların demografik özellikleri için elde edilen sonuçlar ise aşağıda verilmiştir. 
Ali Elibol

\begin{tabular}{|l|l|c|c|c|c|c|}
\hline & Cinsiyet & $\mathbf{n}$ & Ortalama & $\begin{array}{c}\text { Standart } \\
\text { Sapma }\end{array}$ & $\mathbf{p}$ & $\mathbf{T}$ \\
\hline $\begin{array}{l}\text { Dokunsal } \\
\text { Boyut }\end{array}$ & Erkek & 122 & 4,7281 &, 523 & \multirow{2}{*}{, 008} & $-1,601$ \\
\cline { 2 - 5 } & Kadın & 136 & 4,8125 &, 305 & & \\
\hline $\begin{array}{l}\text { Görsel } \\
\text { Boyut }\end{array}$ & Erkek & 122 & 4,6131 &, 519 & \multirow{2}{*}{210} &,- 551 \\
\cline { 2 - 5 } $\begin{array}{l}\text { İşitsel } \\
\text { Boyut }\end{array}$ & Erkek & 136 & 4,6441 &, 379 & & \\
\cline { 2 - 5 } & Kadın & 122 & 4,4863 &, 688 & \multirow{2}{*}{, 143} & $-1,166$ \\
\hline $\begin{array}{l}\text { Tatsal } \\
\text { Boyut }\end{array}$ & Erkek & 136 & 4,5784 &, 579 & & \\
\cline { 2 - 5 } $\begin{array}{l}\text { Kokusal } \\
\text { Boyut }\end{array}$ & Kadın & 122 & 4,5902 &, 550 & \multirow{2}{*}{, 738} &,- 689 \\
\cline { 2 - 5 } & Kadın & 136 & 4,6348 &, 490 & & \\
\hline
\end{tabular}

Tablo 9: Katılımcıların Duyusal Pazarlama Uygulamalarına İlişkin Değerlendirmelerinin Cinsiyetlere Göre Karşılaştırılması T-testi Sonuçları

Duyusal pazarlama uygulamalarının alt boyutları olan dokunsal, görsel, işitsel, tatsal ve kokusal boyutları katılımcıların cinsiyetlerine göre T-testili ile karşılaştırılmış ve elde edilen bulgular Tablo 9'da verilmiştir. Tablo 9'daki veriler ışığında dokunsal boyutun kadınlarda erkeklere kıyasla daha önemli olduğu $(4,8125$ ve ,305) görülmekte ve istatistiksel olarak anlamlı bir farklılığın olduğu sonucuna ulaşılmıştır. Görsel, işitsel, tatsal ve kokusal boyutlarda ise cinsiyetlere göre istatiksel olarak anlamlı bir farklılığın olmadığı tespit edilmiştir $(p>0,05)$. Sonuç olarak elde edilen bu bulgular neticesinde $\mathrm{H}_{7}$ hipotezi kabul edilmiştir.

\begin{tabular}{|c|c|c|c|c|c|c|}
\hline & $\begin{array}{l}\text { Medeni } \\
\text { Durum }\end{array}$ & $\mathbf{n}$ & Ortalama & $\begin{array}{c}\text { Standart } \\
\text { Sapma }\end{array}$ & $\mathbf{p}$ & $\mathbf{t}$ \\
\hline \multirow{2}{*}{ Dokunsal Boyut } & Evli & 160 & 4,7938 &, 33043 & \multirow{2}{*}{,023 } & \multirow{2}{*}{1,024} \\
\hline & Bekâr & 98 & 4,7381 & ,54310 & & \\
\hline \multirow[t]{2}{*}{ Görsel Boyut } & Evli & 160 & 4,6375 & 37864 & \multirow[t]{2}{*}{,092 } & \multirow[t]{2}{*}{,366 } \\
\hline & Bekâr & 98 & 4,6163 & 54936 & & \\
\hline \multirow[t]{2}{*}{ İşitsel Boyut } & Evli & 160 & 4,5938 & ,59660 & \multirow[t]{2}{*}{,014 } & \multirow[t]{2}{*}{1,916} \\
\hline & Bekâr & 98 & 4,4388 & 68296 & & \\
\hline \multirow{2}{*}{ Tatsal Boyut } & Evli & 160 & 4,6396 &, 48740 & \multirow[t]{2}{*}{,256 } & \multirow[t]{2}{*}{1,024} \\
\hline & Bekâr & 98 & 4,5714 & ,56633 & & \\
\hline \multirow[t]{2}{*}{ Kokusal Boyut } & Evli & 160 & 4,7828 & ,44344 & \multirow[t]{2}{*}{,091 } & \multirow[t]{2}{*}{0,95} \\
\hline & Bekâr & 98 & 4,7243 & ,53666 & & \\
\hline
\end{tabular}

Tablo 10: Katılımcıların Duyusal Pazarlamalarına İlişkin Değerlendirmelerinin Medeni Durumlara Göre Karşılaştırılması T-testi Sonuçları

Tablo 10'da katılımcıların duyusal pazarlama uygulamalarına ilişkin değerlendirmelerinin medeni durumlarına göre verilen cevapların gruplar arasında farklılık gösterip göstermediğini incelemek için yapılan T-testi analiz sonuçlarının dağılımı verilmiştir. Elde edilen bu veriler neticesinde dokunsal, görsel, işitsel, tatsal ve kokusal uygulamalarının evli olan katılımcılar için daha önemli olduğu görülmektedir (4,7938 - 4,6375 4,5938 - 4,6396 - 4,7243). Ayrıca Tablo 10'da verilen $p$ değerleri sonucunda gruplar arasındaki farkın istatiksel açıdan anlamsız olduğu gürülmüş $(p>0,05)$ ve $\mathrm{H}_{8}$ hipotezi reddedilmiştir. 


\begin{tabular}{|l|l|c|c|c|c|}
\hline & Cinsiyet & $\mathbf{n}$ & Ortalama & $\begin{array}{c}\text { Standart } \\
\text { Sapma }\end{array}$ & p \\
\hline Müşteri Sadakati & Erkek & 122 & 4,4098 &, 67015 & \multirow{2}{*}{, 105} \\
\cline { 2 - 5 } & Kadın & 136 & 4,5306 &, 59876 & \multirow{2}{*}{. } \\
\hline
\end{tabular}

Tablo 11: Katılımcıların Sadakate İlişkin Değerlendirmelerinin Cinsiyetlere Göre Karşılaştırılması T-Testi Sonuçları

Tablo 11'de müşteri sadakatinin katılımcıların cinsiyetlerine göre karşılaştırılması ve karşılaştırmada gruplar arasında farkın olup olmadığına ilişkin T-testi yapılmıştır. Yapılan analiz sonucunda elde edilen verilere Tablo 11 'de yer verilmiştir. Elde edilen bu sonuçlar neticesinde sadakat bakımından kadınların erkeklere göre daha sadık olduğu görülmüş $(2,1532)$ fakat istatiksel olarak anlamlı bir farklılığın olmadığı tespit edilmiştir $(p>0,05)$. Dolayısıyla bu sonuç ışığında $\mathrm{H}_{9}$ hipotezi reddedilmiştir.

\begin{tabular}{|c|c|c|c|c|c|c|}
\hline & $\begin{array}{l}\text { Medeni } \\
\text { Durum }\end{array}$ & $\mathbf{n}$ & Ortalama & $\begin{array}{c}\text { Standart } \\
\text { Sapma }\end{array}$ & $\mathbf{F}$ & $\mathbf{p}$ \\
\hline \multirow{5}{*}{$\begin{array}{l}\text { Müşteri } \\
\text { Sadakati }\end{array}$} & Evli & 160 & 4,5260 & - 58283 & \multirow[b]{2}{*}{2,902} & \multirow[b]{2}{*}{,090 } \\
\hline & Bekâr & 98 & 4,3878 & ,70580 & & \\
\hline & \multicolumn{2}{|c|}{ Levene Statistic } & df1 & df2 & \multicolumn{2}{|c|}{$\mathbf{P}$} \\
\hline & \multicolumn{2}{|l|}{,962 } & 1 & 256 & \multicolumn{2}{|c|}{,328 } \\
\hline & $\begin{array}{c}\text { Eğitim } \\
\text { Durumları }\end{array}$ & $\mathbf{n}$ & Ortalama & $\begin{array}{c}\text { Standart } \\
\text { Sapma }\end{array}$ & $\mathbf{F}$ & $\mathbf{p}$ \\
\hline \multirow{7}{*}{$\begin{array}{l}\text { Müşteri } \\
\text { Sadakati }\end{array}$} & $\begin{array}{c}\text { İlköğretim- } \\
\text { Ortaokul }\end{array}$ & 40 & 4,3958 & ,63570 & \multirow{5}{*}{,655 } & \multirow{5}{*}{,624 } \\
\hline & Lise & 157 & 4,5106 & 60290 & & \\
\hline & Ön Lisans & 22 & 4,3712 & ,93708 & & \\
\hline & Lisans & 19 & 4,5614 & ,53636 & & \\
\hline & Lisansüstü & 20 & 4,3667 & ,58640 & & \\
\hline & \multicolumn{2}{|c|}{ Levene Statistic } & df1 & df2 & \multicolumn{2}{|c|}{$\mathbf{P}$} \\
\hline & \multicolumn{2}{|l|}{1,365} & 4 & 253 & \multicolumn{2}{|c|}{,246 } \\
\hline & Yaş Aralığı & $\mathbf{n}$ & Ortalama & $\begin{array}{c}\text { Standart } \\
\text { Sapma }\end{array}$ & $\mathbf{F}$ & $\mathbf{p}$ \\
\hline \multirow{8}{*}{$\begin{array}{l}\text { Müşteri } \\
\text { Sadakati }\end{array}$} & $18-29$ & 90 & 4,3519 & ,63573 & \multirow{5}{*}{2,573} & \multirow{5}{*}{,038 } \\
\hline & $30-39$ & 92 & 4,4438 & ,71623 & & \\
\hline & $40-49$ & 60 & 4,6778 & ,48892 & & \\
\hline & $50-59$ & 14 & 4,5714 & ,42725 & & \\
\hline & 60 ve üstü & 2 & 4,5000 & , 70711 & & \\
\hline & \multicolumn{2}{|c|}{ Levene Statistic } & df1 & df2 & \multicolumn{2}{|c|}{$\mathbf{P}$} \\
\hline & \multicolumn{2}{|l|}{1,589} & 4 & 254 & \multicolumn{2}{|c|}{,216 } \\
\hline & $\begin{array}{c}\text { Tatil Yapma } \\
\text { Amacl }\end{array}$ & $\mathbf{n}$ & Ortalama & $\begin{array}{c}\text { Standart } \\
\text { Sapma }\end{array}$ & $\mathbf{F}$ & $\mathbf{p}$ \\
\hline \multirow{6}{*}{$\begin{array}{l}\text { Müşteri } \\
\text { Sadakati }\end{array}$} & Dinlenmek & 76 & 4,4013 & ,64359 & \multirow{4}{*}{1,309} & \multirow{4}{*}{,272 } \\
\hline & Eğlenmek & 90 & 4,4389 & ,61881 & & \\
\hline & $\begin{array}{c}\text { Yeni Yerler } \\
\text { Gezip Görmek }\end{array}$ & 71 & 4,5376 & 67917 & & \\
\hline & Diğer & 21 & 4,1667 & ,48305 & & \\
\hline & \multicolumn{2}{|c|}{ Levene Statistic } & df1 & df2 & \multicolumn{2}{|c|}{$\mathbf{P}$} \\
\hline & \multicolumn{2}{|l|}{1,363} & 3 & 254 & \multicolumn{2}{|c|}{,254 } \\
\hline
\end{tabular}


Tablo 12: Katılımcıların Sadakate İlişkin Değerlendirmelerinin Medeni Durum-Eğitim Durumları-Yaş Aralığı ve Tatil Yapma Amaçları Durumlarına Göre Levene ve Anova Analizi Sonuçları

Tablo 12'de müşteri sadakatinin katılımcıların medeni durum, eğitim durum, yaş aralığı ve tatil yapma amaçları durumlarına göre karşılattırımıştır. Yapılan Anova testi sonucunda elde edilen veriler neticesinde evli katılımcıların bekâr katılımcılara göre daha sadık olduğu görülmesine $(4,5260)$ rağmen gruplar arasında istatiksel olarak anlamlı bir farklılığın olmadığı sonucuna ulaşılmıştır. $\mathrm{Bu}$ nedenle $\mathrm{H}_{10}$ hipotezi reddedilmiştir $(p>0,05)$. Tablo 12 'de katılımcıların eğitim durumları incelendiğinde elde edilen sonuçlar neticesinde lisans mezunlarının en sadık katılımcılar olduğu $(4,5614 ;, 53636)$ ve lisansüstü mezunların ise en düşük sadakate sahip olduğu sonuçlarına ulaşılmıştır (4,3667; ,58640). Ayrıca elde edilen sonuçlara istinaden gruplar arasında istatiksel olarak anlamlı bir farklılığın olmadığı tespit edildiğinden dolayı $\mathrm{H}_{11}$ hipotezi reddedilmiştir $(p>0,05)$. Tablo 12 'de katılımcıların yaş aralıkları incelendiğinde 40-49 yaş aralığında olan katıımcıların en sadık $(4,6778)$ ve 18-29 yaş aralığındaki katılımcıların ise en düşük sadakat düzeyine sahip oldukları $(4,3519)$ sonucuna ulaşılmıştır. Ayrıca Tablo 12 'de p değerinin ,05'den küçük bulunduğu için $(p=, 038<, 05)$ gruplar arasında anlamlı bir farklılığın olduğu tespit edilmiş ve $\mathrm{H}_{12}$ hipotezi kabul edilmiştir. Son olarak Tablo $12^{\prime} \mathrm{de}$ katılımcıların tatil yapma amaçları incelendiğinde yeni yerler gezip görmek amacıyla tatil yapan katılımcıların sadakatlerinin daha yüksek $(4,5376)$ olduğu, diğer amaçlarla tatil yapan katılımcıların sadakatlerinin ise $(4,1667)$ en düşük düzeyde olduğu sonucuna ulaşılmıştır. Ayrıca $p$ değeri incelendiğinde $\mathrm{p}$ değerinin ,05'ten büyük olduğu görülmekte ve bunun neticesinde gruplar arasında istatiksel olarak anlamlı bir farklılığın olmadığı tespit edilmiştir $(p>0,5)$. Bu sonuç doğrultusunda $\mathrm{H}_{13}$ hipotezi reddedilmiştir.

\section{SONUÇ VE ÖNERİLER}

Günümüzde teknolojinin gelişmesi ve özellikle internet kullanımın yaygınlaşması dünyayı tek bir pazar haline getirdiğinden dolayı tüm sektördeki işletmeler yoğun bir rekabet ortamı ile karşı karşıya kalmaktadır. Bu rekabet ortamında başarılı olabilmek ve rakiplerine karşı üstünlük sağlamak için mücadele veren işletmelerden bir tanesi de turizm sektöründe faaliyet gösteren konaklama işletmeleridir. Bu nedenle günümüz konaklama işletmeleri hem müşteri kazanabilmek hem de müşterilerinde sadakat duygusu oluşturabilmek için çeşitli pazarlama strateji uygulamaktadırlar. Bu uyguladıkları stratejilerden bir tanesi duyusal pazarlama uygulamalarıdır. Çünkü gün içerisinde bireyin beş duyu organlarına dış çevreden milyonlarca 
bilgi ve uyarıcılar gelmektedir. Bu uyarıcı veya bilgiler bazen hoş bir koku bazen güzel bir resim veya tasarım bazen bir ses veya müzik bazen de yumuşaklık hissi veren bir kumaşa dokunuş olabilir. Bu uyarıcılar bireylerde farklı duygular ya da hisler oluşturarak onları çok eskilere, çocukluklarına veya unutulmaz anlarına yani hatıralarına götürebilir. Konaklama işletmeleri müşterilerinde bu duyguları yaratabilmek için müşterilerinin beş duyu organlarına en iyi şekilde hitap edebilmek, etkileyebilmek ve dikkatlerini çekebilmek için çaba sarf etmektedirler. Bu çaba neticesinde dikkati çekilen müşteri ile işletme arasında bir bağın oluşması sağlanıp müşterilerin hem ürün veya hizmetleri satın alması hem de müşterilerinde işletmeye karşı sadakat duygusunun oluşması sağlanmış olacaktır.

Bu çalışma, son yıllarda Türkiye'de turizmin popüler destinasyonlarından biri olan ve markalaşan Salda Gölü'nü ziyarete gelen yerli turistler üzerinde yapılan araştırmada konaklama işletmelerindeki duyusal pazarlama uygulamalarının müşteri sadakati üzerindeki etkisini incelemek amacıyla yapılmıştır. Araştırma kapsamında duyusal pazarlama boyutlarının müşteri sadakati üzerindeki etkisini değerlendirmek için kurulan hipotezlerin test edilebilmesi ve araştırma modelinde oluşturulan duyusal uygulamalarının alt boyutlarını belirlemek amacıyla anket formu hazırlanmıştır. Daha sonra araştırmaya katılan 258 katılımcıdan elde edilen veriler sosyal bilimlerde kullanılan SPSS 22.00 programında analiz edilmiştir. Araştırmada literatür taraması, yapılan anket uygulaması ve 258 katılımcıdan elde edilen verilerin analizi sonucunda; duyusal pazarlama boyutlarının etkisinin ve duyusal pazarla uygulamalarının müşteri sadakati üzerindeki etkisinin belirlenmesi konaklama işletmelerinin hangi boyutlara önem vermesi ve bu boyutları nasıl uygulayabilecekleri açısından önem taşımaktadır.

Konaklama işletmelerinde uygulanan müşteri sadakati üzerinde etkisi olan duyusal pazarlama uygulamaları alt boyutlarının belirlenmesi için yapılan bu araştırmada, konaklama işletmelerinde uygulanan duyusal pazarlama uygulamaları ile müşteri sadakati arasındaki ilişkiyi açıklayabilmek için yapılan korelasyon analizi ve basit doğrusal regresyon analizi uygulanmıştır. Analiz sonucunda duyusal pazarlama uygulamalarına ilişkin alt boyutlar olan dokunsal, görsel, işitsel, tatsal ile kokusal boyutlar ile müşteri sadakati önermeleri arasında pozitif yönlü ve anlamlı ilişkiler olduğu sonucuna ulaşılmıştır. Ayrıca araştırmada müşteri sadakati ile duyusal pazarlama uygulamaları arasında pozitif yönde anlamlı bir ilişkinin olduğu sonucuna da ulaşılmıştır. Daha sonra Raz vd. 2008'de yapmış oldukları çalışmada tatsal ve görsel boyutların tüketicilerin tercihlerinde 
olumlu bir etkiye sahip olduğu, Agapito vd. 2012'de yapmış olduğu oldukları çalışmada beş duyusal pazarlama bileşenlerinin turistlerin deneyimlerini etkilediği, Wang ve Haizhong'un 2014'te yapmış oldukları çalışmada dokunsal boyutun müşteri memnuniyeti üzerinde bir etkiye sahip olduğu, Shabgoush ve Wijayanti 2014'te yapmış oldukları çalışmada görme, koku, duyma, dokunma ve tat duyularının tüketici davranışlarını olumlu yönde etkilediği sonuçlarına ulaşmışlardır. Bu bağlamda bu araştırmada elde edilen duyusal pazarlama boyutlarının müşteri memnuniyeti üzerindeki etkili olduğu sonuçları ile örtüştüğü görülmüştür. Ayrıca literatür taramasında ulaşılan duyusal pazarlama kapsamında yapılan çalışmalarda elde edilen tüm sonuçlar ile bu araştırmadaki elde edilen sonuçlar değerlendirildiğinde duyusal pazarlama uygulamalarının müşteri ve müşteri sadakati üzerinde önemli düzeyde etkili olduğu sonucuna ulaşılmıştır.

Araştırmada elde edilen bu sonuçlara göre turizm sektöründe faaliyet gösterecek olan bir konaklama işletmesi pazarlama stratejilerine karar verirken müşterilerin beş duyu organlarını da göz önünde bulundurmaları gerekmektedir. Çünkü araştırmaya katılan katılımcıların konaklama işletmelerini tercih etmesinde ve işletmeye karşı sadakat duygularının oluşmasında beş duyu organlara hitap eden dokunsal, görsel, işitsel, tatsal ve kokusal uyarıcıların etkili olması duyusal pazarlama stratejilerinin konaklama işletmeleri açısından önemli bir düzeye sahip olduğunu göstermektedir. Bu nedenle duyusal pazarlama uygulamaları alt boyutlarını etkin bir şekilde kullanan ve uygulayan konaklama işletmeleri günümüzdeki rekabet ortamında hem başarı hem de rakiplerine karşı üstünlük elde etmiş olacaktır. Ayrıca dokunsal, görsel, işitsel, tatsal ve kokusal yönden müşterilerini duyusal pazarlama uygulamalarına maruz bırakabilen, kendi işletmelerine has özellikler katarak müşterilere bu uygulamaları sunabilen, bu boyutlar sayesinde müşterilerine farklı duygular ve deneyimler yaşatabilen konaklama işletmeleri hem müşteri elde etmiş hem de müşterileri ile işletmeleri arasında bir bağ kurarak sadakat duygusunu yaratmış olacaktır. Turizm sektörünün ana noktasında insan faktörü yer aldığı için duyu ve hisler turizm sektöründe büyük bir öneme sahiptir. Bu nedenle günümüzdeki konaklama işletmeleri müşterilerinin duygu ve hislerine dokunmak zorundadırlar. Bu bakımdan konaklama işletmeleri müşterileri ile bağ kurabilmeleri için kendilerine has duyusal dokunuşlar bulmalı, geliştirmeli ve uygulamalıdırlar. Bu sayede konaklama işletmeleri diğer rakiplerinden sıyrılarak müşteriler tarafından tercih edilebileceklerdir.

Bu çalışma zaman, maliyet ve günümüzde Çin'in Wuhan kentinde ilk kez ortaya çıkan Covid-19 virüsünün Türkiye'de de görülmeye başlaması ve 


\section{Ali Elibol}

Covid-19 virüsünün salgın haline gelmesinden dolayı salgınla mücadele kapsamında devlet tarafından alınan önlem ve kısıtlamalar nedeniyle Burdur genelinde yapılamamış olup sadece Burdur İli Yeşilova ilçesinde yer alan Salda Gölü çevresinde gölü ziyarete gelen 258 yerli turist üzerinde kolayda örnekleme yöntemi ile yapılmıştır. Bu konu üzerinde çalışmak isteyen araştırmacılar ise salgın ortadan kalktıktan sonra farklı bölgelerdeki yerli hatta yabancı turistleri de araştırmalarına dâhil ederek konaklama işletmelerinde uygulanan duyusal pazarlama boyutlarının etkilerini daha kapsamlı araştırmış olacaklar ve ulaştıkları sonuçlar ile turizm sektöründe faaliyet gösteren konaklama işletmelerine daha kapsayıcı önerilerde bulunabilirler.

\section{KAYNAKÇA}

Amerika Pazarlama Birliği, https://www.ama.org/, Erişim: 05.10.2020.

Agapito, D., L., M. (2013). The Role of Sensescapes in Tourist Experiences in Rural Areas, Universidade Do Algarve, Faculdade De Economia, Tese Para Obtenção Do Grau De Doutor Em Turismo, Faro.

Agapito, D., Do Valle, P. O. \& Mendes, J. (2012). Sensory Marketıng and Tourist Experiences, Discussion Papers - Spatial and Organizational Dynamics 10, 7-19.

Akıllıbaş E. (2019). Beş Duyunun Pazarlama Algısındaki Gücü. Bitlis Eren Üniversitesi Akademik İzdüşüm Dergisi 4(1), 97-124.

Altıntaş, M., H. (2000). Tüketici Davranışları. 1. Basım, Bursa: Alfa Basım Yayın Dağıtım.

Atıcı, M. (2019). Duyusal Pazarlamada Marka Parçalamanın Marka Değeri Üzerindeki Etkileri Coca-Cola Örneği. (Yüksek Lisans Tezi). 580264.

Aslan, H., Topaloğlu C., Kılıç, B. \& Yozukmaz, N. (2017). Yiyecek ve İçecek İşletmelerinde Duyusal Pazarlama Uygulamaları. Journal of Tourism and Gastronomy Studies 5(2), 287-300.

Argan M., Özgen C. \& Koç, A. F. (2017). Futbol Seyircilerinin Duyusal Deneyimlerinin Etkinlik, Tatmini Üzerindeki Etkisi. Pazarlama ve Pazarlama Araştırmaları Dergisi 22, 233-248.

Aydemir, İ. (2019). Applications of Sensory Marketing Strategies to Increase Customer Retention in the Turkish Airline Industry Through Customer Experience. (Master's Degree). 565765.

Batı, U. (2018). Marketing ya da Farkething. İstanbul: Destek Yayınları.

Bayuk, M. N. \& Küçük, F. (2007). Müşteri Tatmini Ve Müşteri Sadakati İlişkisi. Marmara Üniversitesi İİBF Dergisi 12(1), 285-292.

Bayram, N. (2009). Sosyal Bilimlerde Spss ile Veri Analizi. Ezgi Kitapevi: Bursa. 


\section{Ali Elibol}

Behremen, C. (2015). Yiyecek ve İçecek İşletmelerinin Nöropazarlama Faaliyetlerinde Duyusal Algıların Etkisi: Psikonörobiyokimya Perspektifi. (Yüksek Lisans Tezi). 389847.

Biswas, D. \& Szocs, C. \& Abell, A. (2019). Extending the Boundaries of Sensory Marketing and Examining the Sixth Sensory System: Effects of Vestibular Sensations for Sitting Versus Standing Postures on Food Taste Perception. Journal of Consumer Research 46(4), 708-724.

Bozpolat, C. (2017). Mağaza Atmosferinin Tüketici Tercihindeki Önemi. TJSS 1(2), 94-103.

Büdün, E. \& Ertürk, Y. D. (2020). Beş Duyu Kullanımı ile Duyusal Markalama: Tüketici Tutumlarını Belirleme Üzerine Bir Odak Grup Çalışması. Üsküdar Üniversitesi İletişim Fakültesi Etkileşim Akademik Dergisi 5, 52-71.

Çakaröz, K. M. (2018). Hızıı Tüketim Mallarında Duyusal Markalama Uyaranlarını Algılama Düzeyi Farklılıkları ile Yeniden Satın Alma Kararı Arasındaki İlişkinin Nörogörüntüleme Teknikleriyle İncelenmesi.

Çağlar, İ. \& Kılıç S. (2005). Pazarlama. 3. Baskı. Ankara: Nobel Yayıncılık. Çanakçı, Y. (2019). Nöromarketing (Duyusal Pazarlama) ve Kalite Algısı Üzerine Bir İnceleme. (Yüksek Lisans Tezi). 592267.

Çatı, K. \& Koçoğlu, C. M. (2008). Müşteri Sadakati ile Müşteri Tatmini Arasındaki İlişkiyi Belirlemeye Yönelik Bir Araştırma. Selçuk Üniversitesi Sosyal Bilimler Enstitüsü Dergisi 19(1), 167-188.

Demiray, B. (2016). Mağaza Deneyiminde Duyusal Öğeler: Ses, Renk ve Işığın Tüketicilerin Kalite Algısı ve İçgüdüsel Satın Alma Davranışları Üzerindeki Etkileri. (Yüksek Lisans Tezi). 431487.

Doğan, H. (2018). Duyusal Pazarlama ve Marka Sadakati İlişkisi: Ev Tekstil ve Dekorasyon Mağazaları Üzerine Bir Araştırma. (Yüksek Lisans Tezi). 530645.

Dick, A. S. \& Basu, K. (1994). Customer Loyalty: Toward an Integrated Conceptual Framework. Journal of the Academy of Marketing Science 22(2), 99-113.

Elder, R. S. (2011). Cognition and Sensory Perception: The Effects of Advertising and Mental Simulation on the Perceptual Consumption Experience. (Doctoral Thesis). 3476311.

Elibol, A. (2020). Tüketici Satın Alma Kararlarında Tüketici Etnosentrizmi ve Sosyo-Psikolojik Faktörlerin Etkisi. Bucak İşletme Fakültesi Dergisi 3(1), 92-130.

Elibol, A. (2020). Yerel Halkının Yeşilova İlçe Turizmine Bakış Açılarının Belirlenmesi. Uluslararası Türk Dünyası Turizm Araştırmaları Dergisi. 5(2), 171-190. 
Esmailpour, H. \& Zakipour, Z. (2016). The Sensory Stimuli Model: Engage with the Consumer Senses for Brand Distinguishes. Journal of Management Sciences 2(4), 212-218.

Erenkol, D. H. A. (2017). Duyusal Markalamanın Marka Farkındalığı Üzerine Etkisi. Marmara Sosyal Araştırmalar Dergisi 11, 16-36.

Erenkol, A. D. \& Ak, M. (2015). Sensory Marketing. Journal of Administrative Sciences and Policy Studies 3(1), 1-26.

Fahrur, A. \& Wijayanti, R. D. M. (2018). The Triangle of Sensory Marketing Model: Does it Stimulate Brand Experience and Loyalty?. Jurnal Bisnis dan Manajemen 8(1), 57-66.

Gegez, A. E. (2010) Pazarlama Araştırmaları. 3. Baskı. Ankara: Beta Basım.

Genco, Stephen J., Andrew P. Pohlmann \& Peter Steidl (2013). Neuro Marketing for Dummies. Canada: John Wiley \& Sons.

Kalay, G. (2019). Duyusal Pazarlamanın Tüketici Tercihleri ve Demografik Değişkenler ile İlişkisi Üzerine Bir Araştırma. (Yüksek Lisans Tezi). 566737.

Gülmez, E. (2017). Marka Tercihinde Duyuların Rolü: Starbucks ve Kahve Dünyası Markalarının Duyusal Markalama Açısından Karşılaştırılması, Gümüşhane Üniversitesi. İletişim Fakültesi Elektronik Dergi 5(1), 5884.

Gürbüz, S. \& Şahin, F. (2018). Sosyal Bilimlerde Araştırma Yöntemleri Felsefe-Yöntem-Analiz. Ankara: Seçkin Akademik ve Mesleki Yayınlar.

Güven, H. (2018). Süpermarket-Hipermarketlerde Kullanılan Duyusal Pazarlama Öğelerinin Analizi. Kesit Akademi Dergisi 4(13), 322-340.

Grıguer, S. (2018). Sensory Marketing and its Impact on Consumer's Behavior. (Master's Thesis). 512355.

Hassan, I. \& Iqbal, J. (2016). Employing Sensory Marketing as a Promotional Advantage for Creating Brand Differentiation And Brand Loyalty. Pakistan Journal of Commerce and Social Sciences 10(3), 725734.

Helmefalk, M. (2019). Browsing Behaviour as a Mediator: The Impact of Multi-Sensory Cues on Purchasing. Journal of Consumer Marketing 36(2), 253-263.

Hulten, B., Broweus, N. \& Van Dijk, M. (2009). What is Sensory Marketing? in: Sensory Marketing. Palgrave Macmillan, London.

Hwang, Y. (2009). More Than Meets the Eye: Development of a Sport Event Stimuli and Destination Image Fit Scale. (Doctoral Thesis). 10841056.

Ifeanyichukw C. D. \& Peter A. (2018). The Role of Sensory Marketing in Achieving Customer Patronage in Fast Food Restaurants in Awka. International Research Journal of Management, IT \& Social Sciences 5(2), 155-163. 


\section{Ali Elibol}

İslamoğlu, A. H. (2010). Turizm Pazarlaması. 1. Baskı. Ankara: Beta Basım. İslamoğlu, A. H. \& Altunışık, R. (2013). Tüketici Davranışları. 5. Baskı. İstanbul: Beta Yayıncllık.

Jang, H. W. \& Lee, S. B (2019). Applying Effective Sensory Marketing to Sustainable Coffee Shop Business Management. Sustainability 11, 217.

Kahvecioğlu, J. (2018). Otel İşletmelerinde Duyusal Pazarlama Uygulamalarının Müşteri Sadakatine Etkisi: Bodrum Örneği. (Yüksek Lisans Tezi). 533447.

Kalay, G. (2019). Duyusal Pazarlamanın Tüketici Tercihleri ve Demografik Değişkenler ile İlişkisi Üzerine Bir Araştırma. (Yüksek Lisans Tezi). Erişim Adresi: http://acikerisim.baskent.edu.tr/handle/11727/4130

Kalay, G. \& Sümer, S. I. (2019). Restoran İşletmelerinde Duyusal Pazarlamanın Tüketici Tercihleri ve Demografik Değişkenler ile İliş̧kisinin İncelenmesi: Samsun İli Örneği. Üçüncü Sektör Sosyal Ekonomi Dergisi 54(3), 1547-1567.

Kanat, A. (2003). Duyu Psikolojisi. 2. Baskı. İzmir: İlya Yayınevi.

Kaplan, O. (2015). Duyularla Marka Parçalama Üzerinden Kavramsal Bir Analiz ve Uygulama Örnekleri. (Yüksek Lisans Tezi). 384099.

Kara, M. \& Temiz, S. (2018). Konaklama Sektöründe Duyusal Markalamanın Önemi: Beş Yıldızıı Bir Otel Örneği. Manas Sosyal Araştırmalar Dergisi 7(3), 455-477.

Klaus, J. H. \& Wiedmann, P. (2018). The Sensory Perception Item Set (SPI): an Exploratory Effort to Develop a Holistic Scale for Sensorymarketing. Willey Psychol Marketing 35, 727-739.

Knox, S. D. (1998). Loyalty-Based Segmentation and the Customer Development Process. European Management Journal 16(6), 729-737.

Kotler, P. (1973). Atmospherics as a Marketing Tool. Journal of Retailing $49(4), 48-64$.

Krey, N. L. T. E. (2016). Enough is Enough! Understanding Environmentally Driven Multisensory. (Doctoral Thesis). 10300684.

Krishna, A. (2016), Algı Gerçektir Beş Duyu Satın Alma Davranışlarını Nasıl Etkiler?. (Çev.). Karal B. 1. Baskı. İstanbul: Ka Kitap Yayınları.

Krishna, A. \& Cian, L. \& Sokolova, T. (2016). The Power of Sensory Marketing in Advertising. Current Opinion in Psychology 10, 142-147.

Krishna, A. \& Schwarz N. (2014). Sensory Marketing, Embodiment, And Grounded Cognition: A Review and Introduction. Journal of Consumer Psychology 24(2), 159-168.

Lee, H.-S. \& Mahony, O. (2005). Sensory Evaluation and Marketing: Measurement of a Consumer Concept. Food Quality and Preference 16(16), 227-235. 
Lindstrom, M. (2007). Duyular ve Marka 5 Duyuyla Güçlü Markalar Yaratmak. İstanbul: Optimist Yayınlar.

LV, X. \& Li, C. S. \& Mccabe, S. (2020). Expanding Theory of Tourists' Destination Loyalty: The Role of Sensory Impressions. Tourism Management 77, 1-12.

Matayeva, G. (2018). Tüketicilerin Demografik Özelliklerine Göre Duyusal Pazarlama Anlayışları: Üniversite Öğrencileri Üzerine Bir Uygulama. (Yüksek Lisans Tezi). 504798.

Mohammed, K. H. A. (2019). Investigating the Effects of Sensory Marketing on Customer Decision-Making Process of Toyota Company in the North Iraq. (Yüksek Lisans Tezi). 607691.

Morgan, T. C. (2013), Psikolojiye Giriş. (Ed.). Karakaş, S. \& Eski, R. 20. Baskı. Ankara: Eğitim Kitapevi Yayınları, 57-257.

Nadanyiova, M., Kliestikova, J. \& Kolencik J. (2018). Sensory Marketing from the Perspective of a Support Tool For Building Brand Value. Economics and Culture 15(1), 96-104.

Neema, A. (2015). Impact of Sensory Marketing on Customer Retention: A Study. (Doctoral Thesis). 27535115.

Odabaşı, Y. \& Barış, G. (2010). Tüketici Davranışı. 9. Basım. İstanbul: Kapital Medya Hizmetleri A.Ş.

Odabaşı, Y. (2017). Postmodern Pazarlama. İstanbul: Mediacat Kitapları.

Oliver, R. L. (1999). Whence Consumer Loyalty?. Journal of Marketing 63, 33-44.

Onar, C. (2018). Duyusal Pazarlama Stratejilerinin Türkiye Perakende Sektöründeki Uygulamaları. (Yüksek Lisans Tezi). 80138.

Oom, Do V. P., Silva, J. A., Mendes, J. \& Guerreiro, M. (2006). Tourist Statisfaction and Destination Loyalty Intention: A Structural and Categorical Anlysis. International Journal of Business Science and Applied Management 1(1), 25-44.

Oppermann, M. (2000). Tourism Destination Loyalty. Journal of Travel Research 39, 78-84.

Özer, N. (2009). Algılama ve Pazarlama Uygulamaları. Paradoks, Ekonomi, Sosyoloji ve Politika Dergisi 5(1), 1-12.

Özer, Ö. \& Günaydın, Y. (2010). Otel İşletmelerinde Müşteri Memnuniyeti ve Müşteri Sadakati İliş̧kisi: Dört Yıldızlı Otel İşletmelerinde Bir Uygulama. Dokuz Eylül Üniversitesi İşletme Fakültesi Dergisi 11(2), 127-154.

Öztel, T. (2019). Duygusal Pazarlamada Slogan Kullanımının Önemi: Pandora Reklamları Üzerine Bir İnceleme. (Yüksek Lisans Tezi). 82256. 
Öztürk, Y. (2019). Koku Markalamanın Satın Alma Davranışı Üzerine Etkisi: Bursa İlinde Hazır Giyim Sektörü Üzerinde Bir Araştırma. (Yüksek Lisans Tezi). 484197.

Pramudya, R. C. (2018). Influences of Intrinsic and Extrinsic Hand-feel Touch Cues on Sensory Perception and Emotional Responses Toward Beverage Products. (Master's Degree). 10845925.

Peck, J. \& Childers, T. L. (2008). Sensory Factors and Consumer Behavior. Handbook of Consumer Psychology, 193-219.

Peker, E. (2017). Duyusal Markalama ve Tüketicilerin Marka Algısında Duyusal Markalamanın (Beş Duyunun) Rolü. (Yüksek Lisans Tezi). 484197.

Petit, O., Velasco, C. \& Spence, C. (2019). Digital Sensory Marketing: Integrating New Technologies Into Multisensory Online Experience. Journal of Interactive Marketing 45, 42-61.

Pullman, M. E. \& Gross, M. A. (2004). Ability of Experience Design Elements to Elicit Emotions and Loyalty Behaviors. Decision Sciences 35, 551578.

Raz, C. \& Piper, D., Haller, R., Nicod, H., Dusart, N. \& Giboreau, Q. (2008). From Sensory Marketing to Sensory Design: How to Drive Formulation Using Consumers' Input?. Food Quality and Preference 19, 719-726.

Rodrigues, C., A., M., C., S. (2014). Brand Sensuality and Consumer-Based Brand Equity. (Doctoral Thesis). 10593303.

Sarıbaş, Ö. \& Demir, C. (2020). Sensory Studies as a Multidisciplinary Research Field and its Use in Tourism Research: A Bibliometric Analysis on Tourism Literature. Turizm Akademik Dergisi 1, 269-283.

Sertel, B. Ö. \& Özkul, H. (2014). Duyum ve Algı Psikolojisi. (Ed.). Sevda Bulduk. İstanbul: Nobel Tıp Kitapevi, 85-283.

Shabgoushah, M. \& Wijayanti, R. D. M. (2014). Towards the Sensory Marketing: Stimulating the Five Senses (Sight, Hearing, Smell, Touch and Taste) and its Impact on Consumer Behavior. Indian Journal of Fundamental and Applied Life Sciences 4(1), 573-581.

Shiffman, L. G. \& Kanuk, L. L. (1994). Consumer Behavior. Prentice Hall.

Stancioiu, A. F., Ditioiu, M. C., Teodorescu, N., Onişor, L. F. \& Pargaru, I. (2014). Sensory Marketing Strategies. Case Study: Oltenia, Theoretical and Applied Economics 21(7), 43-54.

Solomon, M., Bamossy, G., Askegard, S. \& Hoeg, M. K. (2006). Consumer Behavior: A European Perspective. Prentice Hall, Pearson Higher Education: New Jersey.

Thakkar, M. (2008). The Relative Importance of Sensory and Non-Sensory Attributes in Physical and Online Stores: An Evaluability Perspective. (Doctoral Thesis). 3330373. 


\section{Ali Elibol}

Tomaş, M. \& Barutçu, S. (2017). Duyusal Pazarlama Duyusal Etkileşimin Ürün Algılamalarına Etkisi: Yumuşatıcı Ürününde Bir Araştırma. Dumlupınar Üniversitesi Sosyal Bilimler Dergisi Pazarlama Kongresi Özel Sayısı Mayıs, 149-169.

Tosun N., B. \& Elmasoğlu K. (2015). Duyusal Markalamanın Marka Sadakati Üzerindeki Rolü. Maltepe Üniversitesi İletişim Fakültesi Dergisi 2(1), 91-111.

Tuğrul, M., S. (2009). Müşteri Sadakati Sağlamada Bir Pazarlama İletişimi Aracı Olarak Müşteri İlişkileri Yönetimi ve Algılanışı Üzerine Bir Araştırma. (Yüksek Lisans Tezi). 258421.

Uddin, Md. S. (2011). The Impact of Sensory Branding (Five Senses) on Consumer. (Unpublished Master's Thesis). Karlstad Business School, Business Administration, Karlstad.

Uncles, M. D., Dowling, G. R. \& Hammond, K. (2003). Customer Loyalty and Customer Loyalty Programs. Journal of Consumer Marketing 20(4), 294-316.

Yoganathana, V. \& Osburgb, V. S. \& Akhtarb, P. (2019). Sensory Stimulation for Sensible Consumption: Multisensory Marketing for Etailing of Ethical Brands. Journal of Business Research 96, 386-396.

Yeniçeri A., M. (2010). Deneyimsel Pazarlamada Alışveriş Atmosferinin Tüketici Davranışları Üzerindeki Etkisi. (Doktora Tezi). 263295.

Yeygel, Ç. S. (2010). Markaların Duyular Yoluyla Şekillenmesi. Erciyes Üniversitesi İletişim Fakültesi Dergisi 1(4), 39-62.

Yozukmaz, N. (2016), Sensory Marketing Applications in 5-Star Hotels: The Case of Bodrum. (Master's Thesis). 431170.

\section{GENİŞLETİLMİş ÖZET}

\section{Araştırma Problemi}

$\mathrm{Bu}$ araştırma konaklama işletmelerinde uygulanan duyusal pazarlama stratejilerinin ve alt boyutlarının müşteri sadakati üzerindeki etkisini belirlemek amacıyla yapılmıştır. Ayrıca turizm sektöründe faaliyet gösteren konaklama işletmelerine duyusal pazarlama uygulamalarının önemini göstermek ve nasıl uygulayabilecekleri yönünde de yardımcı olabilmek amaçlanmıştır.

\section{Araştırma Soruları}

Araştırma kapsamında, cevaplarda aranmaya çalışılan sorular şunlardır: (1) Konaklama işletmelerinde duyusal pazarlama uygulamalarının müşteri sadakati üzerinde anlamlı bir etkiye sahip midir? (2) Konaklama işletmelerinde dokunsal boyutun müşteri sadakati üzerinde anlamlı bir etkiye sahip midir? (3) Konaklama işletmelerinde görsellik boyutun müşteri sadakati üzerinde anlamlı bir etkiye sahip midir? (4) Konaklama işletmelerinde işitsel boyutun müşteri sadakati üzerinde anlamlı bir etkiye sahip midir? (5) Konaklama işletmelerinde tatsal boyutun müşteri sadakati üzerinde anlamlı bir etkiye sahip midir? (6) Konaklama 


\section{Ali Elibol}

işletmelerinde kokusal boyutun müşteri sadakati üzerinde anlamlı bir etkiye sahip midir? (7) Katılımcıların duyusal pazarlama uygulamalarına ilişkin değerlendirmeleri ile cinsiyetleri arasında farklılık bulunmakta mıdır? (8) Katılımcıların sadakate ilişkin değerlendirmeleri medeni durumlarına göre farklılık göstermekte midir? (9) Katılımcıların sadakate ilişkin değerlendirmeleri ile eğitim duruları arasında farklılık bulunmakta mıdır? (10) Katılımcıların sadakate ilişkin değerlendirmeleri ile tatil yapma amaçları arasında farklılık bulunmakta mıdır?

\section{Metodoloji}

Araştırmanın ana kütlesini Burdur İli ve çevresindeki turizm potansiyel değerleri yüksek olan yerleri ziyarete gelen ziyaretçiler oluşturmaktadır. Fakat maliyet, zaman ve 2019 Aralık ayında Çin'in Wuhan kentinde ilk kez ortaya çıkan Covid-19 virüsünün Türkiye'de de görülmeye başlaması ve Covid-19 virüsünün salgın haline gelmesinden dolayı salgınla mücadele kapsamında devlet tarafından alınan önlem ve kısıtlamalar nedeniyle Burdur İli'nin turizm potansiyeli arz eden tüm bölgelerini ziyaret eden yerli turistler ele alınamamıştır. Bu nedenle Burdur İli'ne bağlı Yeşilova ilçesinde bulunan ve günümüzde Türkiye'nin Maldivler'i olarak markalaşan ve yaz aylarında yoğun bir ziyaretçi akışına sahip olan Salda Gölü'ne ziyarete gelen yerli turistler araştırmaya dâhil edilmiştir. Salda Gölü'nü ziyarete gelen 258 yerli turiste anketör tarafından yüz yüze anket yöntemi uygulanmıştır. Çalışmada bu noktanın seçilmesinin nedeni Türkiye'nin farklı illerinden gelen ve demografik faktörleri farklı olan yerli turistlerin Salda Gölü'ne daha çok uğradıkları gözlemlenmiş ve bu değerlendirmeden hareketle Salda Gölü'ne ziyarete gelen yerli turistlerin araştırma için daha verimli olacağı düşünülmüştür. Araştırmada nicel araştırma yöntemi kullanılmış ve veriler kolayda örnekleme yöntemi ile toplanmıştır. Daha sonra araştırmada analize elverişli 258 anket formu SPSS 22.0 for Windows paket programı ile analiz edilmiştir.

\section{Sonuç ve Öneriler}

Araştırmada ulaşılan temel sonuç duyusal pazarlama uygulamalarına ilişkin alt boyutlar olan dokunsal, görsel, işitsel, tatsal ve kokusal boyutlar ile müşteri sadakati önermeleri arasında ve müşteri sadakati ile duyusal pazarlama uygulamaları arasında pozitif yönde anlamlı bir ilişki olduğu sonucuna ulaşılmıştır. Elde edilen bu sonuçlara göre turizm sektöründe faaliyet gösterecek olan bir konaklama işletmesi pazarlama stratejilerine karar verirken müşterilerin beş duyu organlarını da göz önünde bulundurmaları gerekmektedir. Çünkü araştırmaya katılan katılımcıların konaklama işletmelerini tercih etmesinde ve işletmeye karşı sadakat duygularının oluşmasında beş duyu organlara hitap eden dokunsal, görsel, işitsel, tatsal ve kokusal uyarıcıların etkili olması duyusal pazarlama stratejilerinin konaklama işletmeleri açısından önemli bir düzeye sahip olduğunu göstermektedir. Bundan dolayı turizm sektörünün ana noktasında insan faktörü yer aldığı için duyu ve hisler turizm sektöründe büyük bir öneme sahiptir. Bu nedenle günümüzdeki konaklama işletmeleri müşterilerinin duygu ve hislerine dokunmak zorundadırlar. Bu bağlamda duyusal pazarlama uygulamaları alt boyutlarını etkin bir şekilde 


\section{Ali Elibol}

kullanan ve uygulayan konaklama işletmeleri günümüzdeki rekabet ortamında hem başarı elde etmiş hem de rakiplerine karşı üstünlük sağlamış olacaktır.

\section{EXTENDED ABSTRACT}

\section{Research Problem}

This research was conducted to determine the effect of sensory marketing strategies and sub-dimensions applied in accommodation businesses on customer loyalty. Another aim was to show the importance of sensory marketing practices to accommodation businesses operating in the tourism sector and to assist them on their application.

\section{Research Questions}

Within the scope of the study, the questions that answers were sought for are as follows: (1) Do sensory marketing practices have a significant effect on customer loyalty in accommodation businesses? (2) Does the tactile dimension have a significant effect on customer loyalty in hospitality businesses? (3) Does the visual dimension have a significant effect on customer loyalty in accommodation businesses? (4) Does the audial dimension have a significant effect on customer loyalty in accommodation establishments? (5) Does the gustative dimension have a significant effect on customer loyalty in accommodation businesses? (6) Does the olfactory dimension have a significant effect on customer loyalty in hospitality businesses? (7) Is there a difference between the participants' evaluations on sensory marketing practices and their gender? (8) Do participants' evaluations of loyalty differ according to their marital status? (9) Is there any difference between the participants' evaluations of loyalty and their educational status? (10) Is there any difference between the participants' evaluations of loyalty and their holiday purposes?

\section{Methodology}

The main body of the study consists of visitors who came to visit places with high tourism potential in Burdur Province and its surroundings. However, due to the cost, time and the emergence of the Covid-19 virus which appeared initially in Wuhan, China in Turkey in December 2019 and the precautions and restrictions imposed by the state within the scope of the fighting against the epidemic did not allow the inclusion of domestic tourists visiting all regions with tourism potential in Burdur province. Therefore, domestic tourists visiting Lake Salda in the Yesilova district of Burdur Province which has been branded as the Maldives in Turkey and hosts an intense flow of visitors in the summer were included in the study. Face to face survey method was applied by pollsters to 258 local tourists who came to visit Lake Salda. The reason why this location was selected for the study is because it had been determined that domestic tourists from different provinces of Turkey with corresponding demographic factors were very likely to visit Lake Salda and therefore this spot would be more productive for the study in terms of visiting 


\section{Ali Elibol}

domestic tourists. The quantitative research method was used in the study and the data were collected by convenience sampling method. Subsequently, 258 questionnaire forms suitable for analysis were analyzed with SPSS 22.0 for Windows package program.

\section{Conclusion and Recommendations}

The main result of the study was the determination of a positive and significant relationship between the sub-dimensions of sensory marketing practices, which are the tactile, visual, auditory, gustatory and olfactory dimensions, and customer loyalty suggestions, and between customer loyalty and sensory marketing practices. According to these results, when deciding on the marketing strategies of a hospitality business that will operate in the tourism sector, the five senses of the customers should also be taken into consideration. The fact that tactile, visual, auditory, gustatory and olfactory stimulants that appeal to the five senses are effective in the participants' preference of a hospitality establishment in the study and the formation of loyalty towards the business shows that sensory marketing strategies hold an important position in terms of accommodation businesses. Therefore, since the human factor is the main point of the tourism sector and senses and feelings have a great importance in the sector, current hospitality businesses have to accommodate the emotions and feelings of their customers. Hence, accommodation businesses that effectively use and implement the sub-dimensions of sensory marketing applications will achieve both success and superiority over their competitors in today's competitive environment. 